\title{
Diet Transition from High-Forage to High-Concentrate Alters Rumen Bacterial Community Composition, Epithelial Transcriptomes and Ruminal Fermentation Parameters in Dairy Cows
}

\author{
Sonny C. $\operatorname{Ramos}^{1}{ }^{(\mathbb{D}}$, Chang Dae Jeong ${ }^{1}$, Lovelia L. Mamuad ${ }^{1}{ }^{\mathbb{D}}$, Seon Ho Kim ${ }^{1}$, Seung Ha Kang ${ }^{2}$, \\ Eun Tae Kim ${ }^{3}$ D, Yong Il Cho ${ }^{4}$, Sung Sill Lee ${ }^{5}$ id and Sang Suk Lee ${ }^{1, *}$ \\ 1 Ruminant Nutrition and Anaerobe Laboratory, Department of Animal Science and Technology, \\ Sunchon National University, Suncheon 57922, Korea; ynnosomarc@yahoo.com.ph (S.C.R.); \\ cdvf12@hanmail.net (C.D.J.); loveliamamuad2306@gmail.com (L.L.M.); mhs0425@hanmail.net (S.H.K.) \\ 2 The University of Queensland Diamantina Institute, Faculty of Medicine, The University of Queensland, \\ Brisbane, QLD 4072, Australia; kansbio@gmail.com \\ 3 Dairy Science Division, National Institute of Animal Science, Rural Development Administration, \\ Cheonan 31000, Korea; etkim77@korea.kr \\ 4 Animal Disease and Diagnostic Laboratory, Department of Animal Science and Technology, \\ Sunchon National University, Suncheon 57922, Korea; ycho@scnu.ac.kr \\ 5 Institute of Agriculture and Life Science and University-Centered Labs, Gyeongsang National University, \\ Jinju 52828, Korea; lss@gnu.ac.kr \\ check for \\ * Correspondence: rumen@scnu.ac.kr; Tel.: +82-61-750-3237
}

updates

Citation: Ramos, S.C.; Jeong, C.D.; Mamuad, L.L.; Kim, S.H.; Kang, S.H.; Kim, E.T.; Cho, Y.I.; Lee, S.S.; Lee, S.S. Diet Transition from High-Forage to High-Concentrate Alters Rumen Bacterial Community Composition, Epithelial Transcriptomes and Ruminal Fermentation Parameters in Dairy Cows. Animals 2021, 11, 838. https://doi.org/10.3390/ani11030838

Academic Editor: Francesca Bennato

Received: 19 February 2021

Accepted: 12 March 2021

Published: 16 March 2021

Publisher's Note: MDPI stays neutral with regard to jurisdictional claims in published maps and institutional affiliations.

Copyright: (c) 2021 by the authors. Licensee MDPI, Basel, Switzerland. This article is an open access article distributed under the terms and conditions of the Creative Commons Attribution (CC BY) license (https:// creativecommons.org/licenses/by/ $4.0 /)$.
Simple Summary: Cattle are fed a high-concentrate diet to improve their productivity; however, it alters the rumen ecosystem due to high structural carbohydrates level, resulting in ruminal acidosis. This study investigated the effect of changing diet on ruminal fermentation parameters, bacterial community composition, and expressed genes of Holstein Friesian cows, with changes induced by transition from a high-forage to two succeeding high-concentrate diets, and then returned to a high-forage diet. Ruminal pH drastically decreased; however, ammonia nitrogen, and individual and total volatile fatty acid (VFA) concentrations increased during the high-concentrate diet period. High-concentrate diet also reduced rumen bacterial richness and diversity. Gene expression in rumen epithelia was affected and altered by changing diet through the obtained differentially expressed genes.

Abstract: Effects of changing diet on rumen fermentation parameters, bacterial community composition, and transcriptome profiles were determined in three rumen-cannulated Holstein Friesian cows using a $3 \times 4$ cross-over design. Treatments include HF-1 (first high-forage diet), HC-1 (first high-concentrate diet), HC-2 (succeeding high-concentrate diet), and HF-2 (second high-forage diet as a recovery period). Animal diets contained Klein grass and concentrate at ratios of 8:2, 2:8, 2:8, and 8:2 (two weeks each), respectively. Ammonia-nitrogen and individual and total volatile fatty acid concentrations were increased significantly during HC-1 and HC-2. Rumen species richness significantly increased for HF-1 and HF-2. Bacteroidetes were dominant for all treatments, while phylum Firmicutes significantly increased during the HC period. Prevotella, Erysipelothrix, and Galbibacter significantly differed between HF and HC diet periods. Ruminococcus abundance was lower during HF feeding and tended to increase during successive HC feeding periods. Prevotella ruminicola was the predominant species for all diets. The RNA sequence analysis revealed the keratin gene as differentially expressed during the HF diet, while carbonic-anhydrase I and S100 calcium-binding protein were expressed in the HC diet. Most of these genes were highly expressed for HC-1 and HC-2. These results suggested that ruminal bacterial community composition, transcriptome profile, and rumen fermentation characteristics were altered by the diet transitions in dairy cows.

Keywords: dairy cows; changing diet; rumen fermentation; bacterial community; transcriptome 


\section{Introduction}

Dairy cattle feeding patterns have been changed to provide the required energy and nutrients by feeding them concentrate feeds instead of fiber-rich forages [1]. Dairy cattle frequently undergo dietary transitions to meet the energy requirements for milk production around the start of their lactation period [2]. Such dietary transitions have supported the increase in milk yields; however, they raise concerns about rumen function in these cattle $[1,3,4]$. These dietary transitions affect chewing behavior and rumen buffering, which may lead to accumulation of large amounts of volatile fatty acids (VFA) in the rumen fluid [5]. Furthermore, the transition of the diet from high forage to high grain results in greater VFA concentrations and accumulation of lactate in the rumen, thus increasing the risk of subacute ruminal acidosis (SARA) [6-10]. SARA has been associated with metabolic and microbial alterations, and imbalances in the rumen, which are involved in metabolic health disorders in dairy cattle [11,12]. Among its various manifestations, it reduces cellulolytic bacteria counts, leading to impairment of bacterial activity due to undesirable ruminal $\mathrm{pH}$, which may result in low fiber degradation [13-16]. Energy and essential nutrients are mainly obtained by ruminants through a complex symbiotic relationship with the rumen microbiome [17]. The health and efficiency of the host ruminants are significantly affected by changes in the bacterial community in the rumen [18]. While a high-forage diet is usually switched to a high-concentrate diet to improve the productivity of ruminants, it can alter the rumen ecosystem [17].

The rumen is a complicated environment of microbes and hosts numerous amounts of bacteria that constitute an efficient mutual relationship of host animal and microorganisms [19-21]. Ruminants rely on ruminal microbes for the degradation of structural carbohydrates, and VFA and microbial protein synthesis served as the main sources of protein and energy [22]. The combined activities of a wide range of bacterial community in the rumen metabolizes the carbohydrates from feed [23]. Normally, various groups of bacteria are used to specialize for the utilization of specific types of polysaccharides, such as starch or cellulose, which are known to be digested by saccharolytic and cellulolytic bacteria, respectively [24]. Starch is one of the most abundant polysaccharides found in high-grain diets, which are mainly used to increase animal performance and are more favorable to saccharolytic bacteria [25-28]. However, the use of starch-rich feedstuffs was associated with the reduction of bacterial richness and diversity in the rumen and large intestines [23], which resulted in a decrease in relative abundance of Bacteroidetes and an increase in case of Firmicutes [29-31]. Ruminal saccharolytic bacteria can be considered as potential initiators of SARA, as higher starch basically results in greater production rates of short-chain fatty acids [23]. A previous study investigated the impact of SARA on the rumen microbial community using high-throughput $16 \mathrm{~S}$ rRNA sequencing and found that there was a major shift in the three dominating phyla [1]. Another next-generation sequencing (NGS) technique is the RNA sequencing technology, which is an indispensable tool for meta-transcriptome analysis of different gene expression [32]. Meta-transcriptome analysis is more powerful compared to other NGS methods because of the information it can provide about microbial populations that are transcriptionally active [33], as well as the in-depth analysis of functional gene activity and metabolic pathways [34]. However, meta-transcriptome analysis in rumen with regards to SARA is limited [35]. In addition, despite adaptation and recovery of rumen bacteria during SARA challenge through high grain-feeding, the effect of changing diet in dairy cattle is largely unclear. This study was, therefore, undertaken to investigate the effect of changing diet on ruminal fermentation parameters, bacterial community composition, and transcriptome profile of Holstein Friesian cows, with changes induced by transition from a high-forage diet to two succeeding highconcentrate diets and then back to a high-forage diet. The findings provide plausible information that diet transitions would induce changes in ruminal $\mathrm{pH}$ and fermentation ability, consequently altering rumen bacterial community composition and transcriptome profile in dairy cows. 


\section{Materials and Methods}

\subsection{Animal Care}

This study was conducted at the Sunchon National University (SCNU) animal farm and in the Ruminant Nutrition and Anaerobe Laboratory, the Department of Animal Science and Technology, SCNU, Suncheon, Jeonnam, Korea. The animals used and all experimental protocols were reviewed and approved by the Sunchon National University Animal Research Ethics Committee (SCNU IACUC, approval number: SCNU IACUC-2018-01).

\subsection{Animals, Feeding, and Experimental Design}

Three rumen-cannulated Holstein Friesian cows, with average body weights of $600 \pm 47 \mathrm{~kg}$, were used in this study. A $3 \times 4$ cross-over design was used for this experiment to evaluate the effects of changing diet on rumen fermentation, bacterial composition, and transcriptome profile of the animals. This changing diet challenge was defined as the high-forage period followed by two succeeding high-concentrate periods, and then a return to the high-forage period to investigate the changes in ruminal $\mathrm{pH}$ and the adaptive capability of the rumen microbiome. Prior to the experiment, cows were fed with mixed Klein grass hay and concentrate at a ratio $(\mathrm{kg})$ of 8:2. During the experimental period, all cows were fed twice a day continuously with the same diet ratio for 2 weeks. Then, after the first period, diet was changed to the ratios (forage:concentrate) as follow: 2:8 (2 weeks), 2:8 (2 weeks), and 8:2 (2 weeks). These feeding ratios served as treatments (HF-1 (first high-forage diet), HC-1 (first high-concentrate diet), HC-2 (succeeding high-concentrate diet, and HF-2 (second high-forage diet, served as a recovery period)). The HF-1 consisted of dairy cows fed a high-forage diet for 2 weeks. Then, it was followed by HC-1, which involved the same group of cows fed for 2 weeks with high-concentrate right after the HF-1 period prior to acidosis. Afterwards, a succeeding 2 weeks of feeding with highconcentrate diet were allotted for HC-2 in the same group of cows, followed by a transition to a high-forage diet (HF-2), which served as a recovery period for the animals. Animals were housed in individual stalls and had free access to water. The concentrate given to dairy cows was supplied by Purina ${ }^{\circledR}$ Cargill, Korea. The chemical compositions of the forage and concentrate fed to the dairy cows are shown in Table 1.

Table 1. Composition of the Klein grass and concentrate on percentage.

\begin{tabular}{ccc}
\hline Item $^{\mathbf{1}}$ & Klein Grass & Concentrate \\
\hline Chemical composition (\%) & & 13.03 \\
Crude Protein & 12.70 & 3.84 \\
Crude Fat & 1.06 & 5.77 \\
Crude Ash & 8.73 & 77.00 \\
TDN & 60.18 & 1.00 \\
Calcium & 0.43 & 0.48 \\
Phosphorus & 0.14 & 23.44 \\
NDF & 59.57 & 9.92 \\
ADF & 36.09 & 0.84 \\
Potassium & 1.76 & 0.24 \\
Magnesium & 0.48 & 0.21 \\
Sodium & 0.18 & \\
\hline
\end{tabular}

${ }^{1} \mathrm{TDN}$, total digestible nutrients; NDF, neutral detergent fiber; ADF, acid detergent fiber.

\subsection{Rumen Fluid Collection and Analysis of Ruminal Fermentation Parameters}

Ruminal contents were collected from the three rumen-cannulated cows before morning feeding on the last day of each period before transitioning to the next diet period. The fluid samples were squeezed and strained through a four-layer surgical gauze and placed in an amber bottle, which was subsequently capped after collection. The collected fluid samples were maintained at $39^{\circ} \mathrm{C}$ and immediately transported to the laboratory for analysis of the ruminal fermentation parameters. An aliquot of rumen fermenta was separated from the sample bottles, transferred to two $1.5 \mathrm{~mL}$ microcentrifuge tubes, and 
stored at $-80{ }^{\circ} \mathrm{C}$, prior to ammonia-nitrogen $\left(\mathrm{NH}_{3}-\mathrm{N}\right)$ and VFA analyses. Following this, the samples were thawed at room temperature and were centrifuged for $10 \mathrm{~min}$ at $13,000 \mathrm{rpm}$ at $4{ }^{\circ} \mathrm{C}$ using a Micro 17TR centrifuge (Hanil Science Industrial, Korea). The obtained supernatant was used for $\mathrm{NH}_{3}-\mathrm{N}$ and VFA concentration analyses. The $\mathrm{NH}_{3}-\mathrm{N}$ concentration was measured according to the colorimetric method developed by Chaney and Marbach [36] using a Libra S22 spectrophotometer (Biochrom Ltd., CB40FJ, Cambridge, UK) at an absorbance of $630 \mathrm{~nm}$. The analysis of the VFA concentration was done using high-performance liquid chromatography (Agilent Technologies 1200 series, Tokyo, Japan) with an ultraviolet (UV) detector set at 210 and $220 \mathrm{~nm}$. Samples were isocratically eluted with $0.0085 \mathrm{~N} \mathrm{H}_{2} \mathrm{SO}_{4}$ at a flow rate of $0.6 \mathrm{~mL} / \mathrm{min}$ and a column temperature of $35^{\circ} \mathrm{C}$ [37].

\subsection{Metataxonomic and Transcriptomics Analyses}

Rumen fluid samples for metataxonomic analysis and rumen tissue biopsies for transcriptomics analysis were obtained from each treatment, and were sent to Macrogen (Seoul, Korea) for sample preparation, library construction, sequencing, and data analysis.

For metataxonomic analysis, after quality assessment of extracted DNA from the samples, a survey of bacterial community composition was performed. Libraries were constructed by targeting the V3-V4 variable regions of the $16 \mathrm{~S}$ ribosomal RNA (rRNA) gene using Herculase II Fusion DNA Polymerase Nextera XT Index Kit V2 following the Illumina's 16S Metagenomic sequencing library preparation. After assessing the quality of the constructed libraries, sequencing was done using the Illumina sequencing platform (Miseq). Then, the generated paired-end (PE) sequencing raw reads from the base call binary data obtained by real-time analysis were converted to fastq format. Filtering of PE raw reads from overhang adapter sequences were done, then the filtered PE reads were merged. Quality filtering, trimming of short and extra-long reads, and removal of duplicate reads were done, then the filtered reads were clustered at $100 \%$ identity using CD-HIT-OTU [38]. After identifying chimeric reads, noise filtering was done, and the remaining clusters were binned to operational taxonomic units (OTU) with a cut-off value of $97 \%$ species level identity using the same program. Afterwards, taxonomic assignment of representative sequences from observed OTUs were matched by BLAST on the NCBI 16S rRNA database using Quantitative Insights Into Microbial Ecology (QIIME-UCLUST) [39]. The bacterial diversity was graphically presented using Metagenomics Core Microbiome Exploration Tool (MetaCOMET) [40] by uploading a biological observation matrix to the web server [41], generated using Mothur [42].

For transcriptomics analysis of the host's response to challenge diet, total RNA were extracted from the rumen epithelial tissue biopsy. DNA contamination was eliminated using DNAse. After quality assessment of extracted RNA from the samples, libraries were prepared using the TruSeq Stranded Total RNA LT Sample Prep Kit (Illumina, San Diego, CA, USA) with Ribo-Zero following the manufacturer's Prep Guide. Sequencing was carried out using the TruSeq 30004000 SBS Kit v3 in an Illumina HiSeq 4000 sequencer (Illumina, San Diego, CA, USA). The sequenced raw reads were subjected to quality control by calculating the overall reads' quality, total bases, total reads, and guanine-cytosine (GC) percentage. Then, sequencing artifacts like low-quality reads and adapter sequences were filtered out using Trimmomatic [43]. The remaining trimmed reads were then mapped against cow reference genome (Bos_taurus_UMD_3.1.1/bosTau8) retrieved from the University of California Santa Cruz genome database website (genome.ucsc.edu), using hierarchical indexing for spliced alignment of transcripts 2 (HISAT2) [44] by handling spliced reads mapping using Bowtie2 aligner [45]. Transcripts were assembled using StringTie [46] with aligned reads to provide information of known, novel, and alternative splicing transcripts based on the reference genome model. Afterwards, the level of abundance of transcripts in fragments per kilobase of transcript per million mapped reads (FPKM) was normalized. The FPKM value of known genes was used to sort the differentially expressed genes among samples. Three comparison pairs were conducted, where sample HF-1 served as the point of comparison of the three samples to determine whether a certain known gene was up- 
or down-regulated between diet types. During this analysis, low-quality transcripts were filtered, then the FPKM normalization was performed. Statistical analysis was performed using Fold Change per comparison pair (fc), and significant genes were selected if the fold change per comparison pair was greater than or equal to two. Afterwards, hierarchical clustering analysis was performed among the significant genes in order to group the genes and samples based on similarity of expression patterns.

\subsection{Statistical Analysis}

All analyses were carried out using Statistical Analysis Systems (SAS) software version 9.4 (SAS Institute 2012) (SAS Institute Inc., Cary, NC, USA). Data were statistically evaluated using Proc Glimmix for a complete randomized design. The experiment was done twice, and the treatments were conducted in triplicate. Least square means was used to identify differences among treatments. A $p<0.05$ was considered indicative of significant differences.

\section{Results}

\subsection{The Effects of Treatments on Rumen Fermentation Parameters}

The ruminal $\mathrm{pH}$ was significantly higher $(p=0.001)$ during the high-forage diets. As the feeding switched to a high-concentrate diet, a lower ruminal $\mathrm{pH}$ was observed. The rumen $\mathrm{pH}$ of $\mathrm{HC}-1$ and $\mathrm{HC}-2$ was significantly $(p=0.001)$ lower than the HF periods due to the high concentrate ratio in the diet. The $\mathrm{NH}_{3}-\mathrm{N}$ concentrations for HF-1 and HF-2 were significantly lower $(p=0.001)$ and had an opposite result to the cows receiving the high-concentrate diet. Furthermore, in the HC diet group, the individual and total VFA concentrations were significantly higher $(p=0.001)$ than the HF group. The acetate to propionate ratio was significantly lower $(p=0.001)$ during HC-1 and HC-2, then during the HF feeding period, an opposite result was observed. Meanwhile, a significantly lower $(p=0.001)$ VFA concentration was observed during the HF diet periods (Table 2).

Table 2. Rumen fermentation profile of Holstein Friesian cows fed with different diet ratio.

\begin{tabular}{|c|c|c|c|c|c|c|}
\hline \multirow{2}{*}{ Parameters } & \multicolumn{4}{|c|}{ Treatments ${ }^{1}$} & \multirow{2}{*}{ SEM $^{2}$} & \multirow{2}{*}{$p$-Value } \\
\hline & HF-1 & HC-1 & HC-2 & HF-2 & & \\
\hline $\mathrm{pH}$ & $6.87^{\mathrm{a}}$ & $5.58^{b}$ & $5.41^{b}$ & $6.89^{a}$ & 0.098 & $<0.001$ \\
\hline $\mathrm{NH}_{3}-\mathrm{N}(\mathrm{mg} / \mathrm{dL})$ & $4.88^{\mathrm{b}}$ & $10.99^{a}$ & $11.37^{\mathrm{a}}$ & $5.04^{b}$ & 0.896 & $<0.001$ \\
\hline Total VFA (mmol/L) & $92.39^{b}$ & $154.59^{\mathrm{a}}$ & $149.33^{a}$ & $85.28^{b}$ & 7.577 & $<0.001$ \\
\hline \multicolumn{7}{|l|}{ VFA (mmol/L) } \\
\hline Acetate & $70.12^{b, c}$ & $95.25^{\mathrm{a}}$ & $86.10^{a, b}$ & $61.05^{c}$ & 6.072 & 0.010 \\
\hline Propionate & $14.92^{b}$ & $39.73^{\mathrm{a}}$ & $40.15^{\mathrm{a}}$ & $15.76^{\mathrm{b}}$ & 5.038 & 0.001 \\
\hline Butyrate & $7.36^{\mathrm{b}}$ & $19.60^{\mathrm{a}}$ & $23.08^{a}$ & $8.47^{\mathrm{b}}$ & 1.188 & $<0.001$ \\
\hline $\mathrm{A} / \mathrm{P}$ ratio & $4.73^{\mathrm{a}}$ & $2.70^{b, c}$ & $2.25^{c}$ & $4.04^{\mathrm{a}, \mathrm{b}}$ & 0.437 & 0.001 \\
\hline
\end{tabular}

${ }^{1}$ Treatments: HF-1 (high-forage diet); HC-1 (high-concentrate diet); HC-2 (high-concentrate diet); HF-2 (highforage diet). ${ }^{a-c}$ Means with different superscripts in a row differ significantly $(p<0.05) .{ }^{2}$ SEM: standard error of the mean. VFA, volatile fatty acid; $\mathrm{A} / \mathrm{P}$, acetate to propionate ratio.

\subsection{General Ruminal Bacterial Community Composition}

The bacterial community of the rumen microbiome after diet transition is presented as a Venn diagram in Figure 1a. Out of 353 overall representative species of observed OTUs, a total of 125 (35.4\%) were present across all communities (core), 142 (40.23\%) were observed as shared by 2 or 3 communities, and a total of $86(24.36 \%)$ were distributed uniquely in the four communities. This figure also shows that as the diet changes from high forage to high concentrate, the number of bacterial species also increases. However, at the point when the diet was reverted back to high forage (HF-2), the number of bacterial species decreased, but was still of higher count compared to HF-1. It can also be noted that these bacteria uniquely shared between two communities were higher between the same diet (HF-1 and HF-2: 27, HC-1 and HC-2: 32) compared to shared species between different 
diet types (HF-1 and HC-1: 1, HF-1 and HC-2: 6, HC-1 and HF-2: 5), except between HC-2 and HF-2, for which the number of species observed was higher than ten. The unweighted unifrac diversity principal coordinate analysis ( $\mathrm{PCOA})$ plots showed a similarity within the diet changing stage (Figure 1b). The high-forage diet periods (HF-1 and HF-2) had similar bacterial communities with non-distinct clusters and no spatial separation among populations. A portion of the bacterial community of HC-2 was also related to HF-2 due to the transition of the diet from high-concentrate to high-forage. There was also a tendency toward more similar bacterial communities between the high-concentrate diet periods (HC-1 and HC-2).
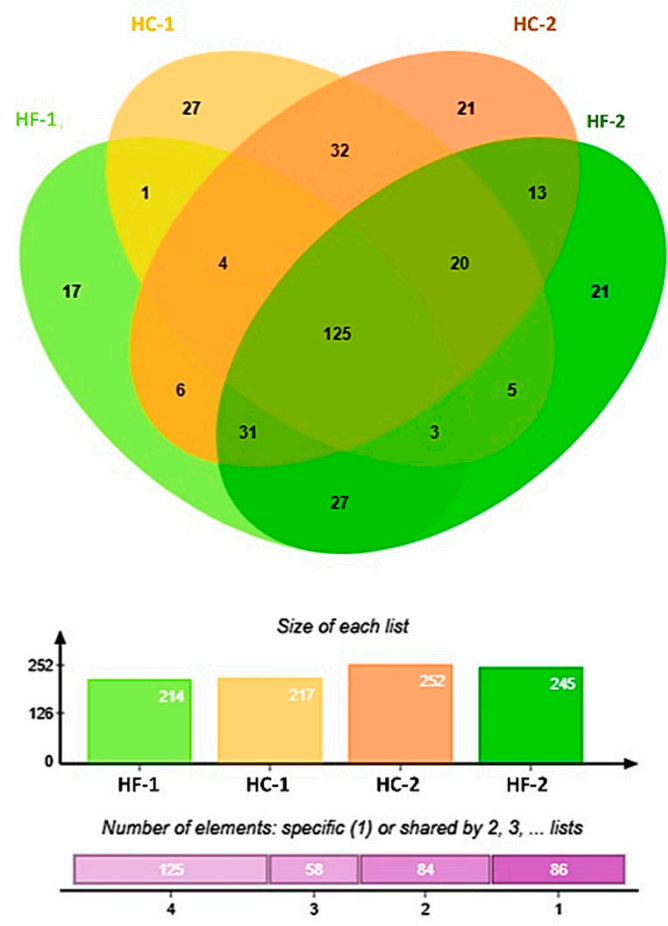

(a)

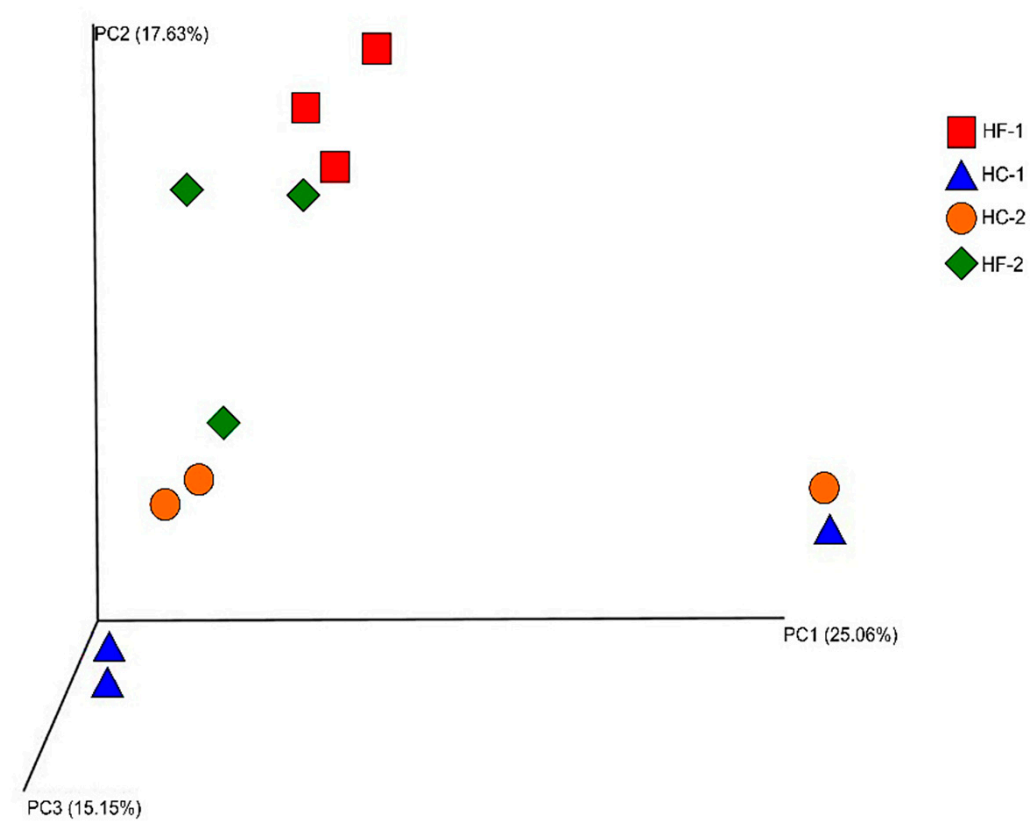

(b)

Figure 1. Venn diagram of rumen microbiome after transition of diet from high forage (HF-1) to high concentrate (HC-1 to HC-2), and back to high forage (HF-2), representing the unique, shared, and core microbiome. The bar graph below shows the size of representative species of observed operational taxonomic units (OTUs) per treatment. (a) Venn diagram was generated using jVenn [47]. (b) Principal coordinate analysis (PCoA) of all samples using Bray-Curtis distance derived from the subset of identified OTUs. EMPeror [48] was used to generate the PCoA plot. HF-1, high-forage diet; HC-1, high-concentrate diet; HC-2, high-concentrate diet; HF-2, high-forage diet.

A total of 15 bacterial phyla were identified within the rumen bacteria communities. The most abundant phyla included Bacteroidetes, Firmicutes, and Actinobacteria. With these phyla, Bacteroidetes was dominant in all treatments. However, its relative abundance decreased as cattle received a high-concentrate diet and a notable increase in abundance when the diet changed to high forage. This was contrary to the relative abundances of Firmicutes. As the rumen was subjected to the high-concentrate diet condition, the abundance of Firmicutes significantly increased $(p=0.039)$. A similar response was observed with the phylum Actinobacteria. Its abundance increased as the high-concentrate diet condition was prolonged (Figure 2a). 


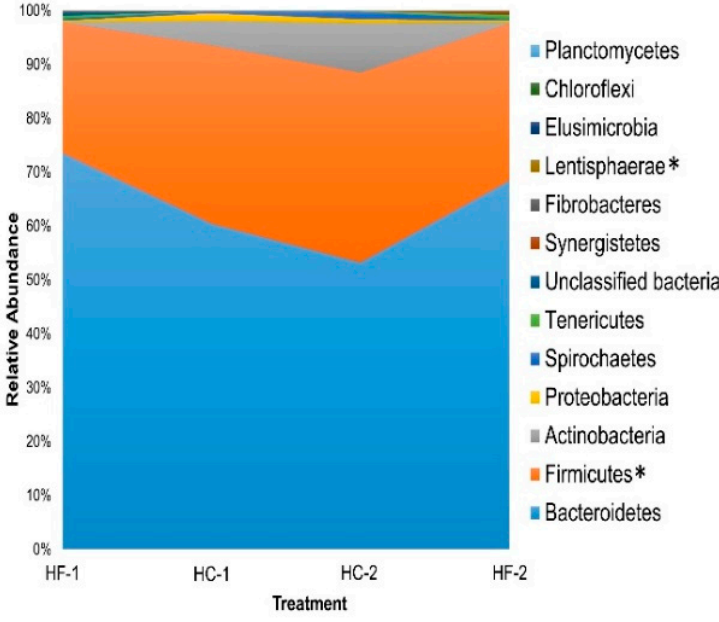

(a)

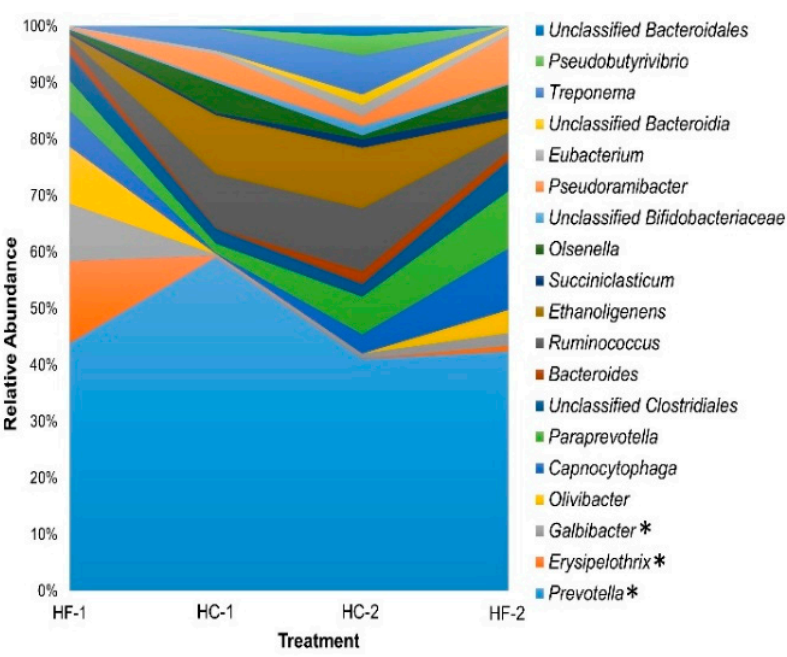

(b)

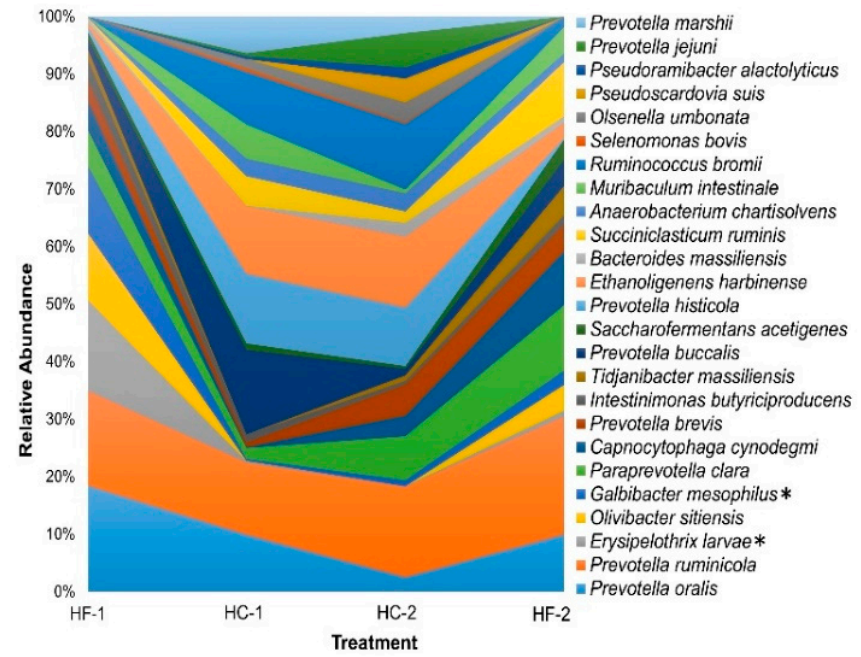

(c)

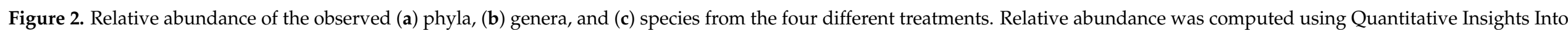

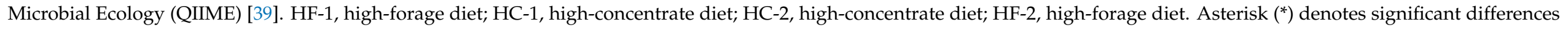
$(p<0.05)$. 
The analysis of genus level composition revealed 143 identified genera, of which 19 were dominant ( $>1 \%$ of the relative abundance) (Figure $2 \mathrm{~b}$ ). The relative abundance of Prevotella, Erysipelothrix, and Galbibacter significantly differed between the high-forage and the high-concentrate diet periods $(p<0.05)$. Prevotella had a higher relative abundance during the first high-concentrate diet period. However, it significantly decreased $(p=0.024)$ as the high-concentrate diet was continuously supplied to cows. Meanwhile, Erysipelothrix and Galbibacter both showed similar responses to the treatments. These genera significantly decreased their abundances as the diet transitioned from high forage to high concentrate $(p<0.05)$, and gradually increased as the rumen recovered with the return to the highforage diet. Ruminococcus had lower abundances under the high-forage diet period and tended to increase in abundance, though not significantly, during the two subsequent high-concentrate diet periods $(p=0.086)$. A similar pattern as with Ruminococcus was observed in the case of Ethanoligenes and Treponema, which showed high abundance during the periods of high-concentrate diet and the least in both high-forage diets.

At the species level, Prevotella ruminicola was the most dominant species for all treatments, with relative abundances of $12.61 \%, 9.57 \%, 11.70 \%$, and $14.67 \%$, respectively (Figure 2c). Its abundance decreased as the diet transitioned from the high-forage diet to the high-concentrate diet. Meanwhile, as the high-concentrate diet period continued, a notable increase in abundance was observed. A similar scenario was observed with Paraprevotella clara, Prevotella brevis, and Capnocytophaga cynodegmi. The transition of the diet from high forage to high concentrate increased the abundances of Ethanoligenens harbinense, Ruminococcus bromii, Prevotella histicola, Prevotella jejuni, Olsenella umbonata, Anaerobacterium chartisolvens, and Pseudoramibacter alactolyticus. There was also a continual increase in their relative abundances when the high-concentrate diet was supplied consecutively. Furthermore, Prevotella oralis and Olivibacter sitiensis had a drastic reduction of abundance after changing the diet from a high-forage to a high-concentrate diet; however, these particular species recovered when the diet returned back to a high-forage one. In case of Prevotella buccalis and Prevotella marshii, the contrary was observed when the diet was shifted from high-forage to high-concentrate. The relative abundance radically increased, but as the high-concentrate diet continued, a remarkable decrease in abundance was noticed. A statistical comparison of single species showed a significant effect of treatments only in the case of Galbibacter mesophilus and Erysipelothrix larvae. These species were both significantly more abundant for treatments with the high-forage diet $(p=0.006 ; p=0.010)$. A heatmap was also generated showing the relationship of each bacterial species on the $\mathrm{pH}$ values of treatments clustered based on Pearson correlation (Figure S1).

The normalized data presented in Figure 3 shows the clustering based on similarity of relative abundance of families and treatments. The four communities after the diet transitions were clustered based on diet type, indicating close similarity of family abundance in each diet type. On the other hand, families were clustered based on their relative abundance, distinguishable by color based on their normalized value, by which two major clusters were formed: cluster of families with low relative abundance (lower cluster), and families with higher relative abundance (upper cluster). Distinctly observed is a subcluster containing the highest relative abundance, and among the families in this cluster, Ruminococcaceae, Flavobacteriaceae, Erysiopelotrichaceae, and Rikenellaceae displayed significant differences $(p<0.05)$ between treatments. Family Ruminococcaceae was initially lower during the HF diet, but significantly increased as the diet was altered to HC, and dropped when the diet was reverted to HF. This pattern was oppositely observed in Family Flavobacteriaceae, wherein abundance had decreased when changed to HC, then increased significantly when diet was reverted to HF. At the same time, Families Erysipelotrichaceae and Rikenellaceae were observed to be higher in HF1 and HF2, respectively. 


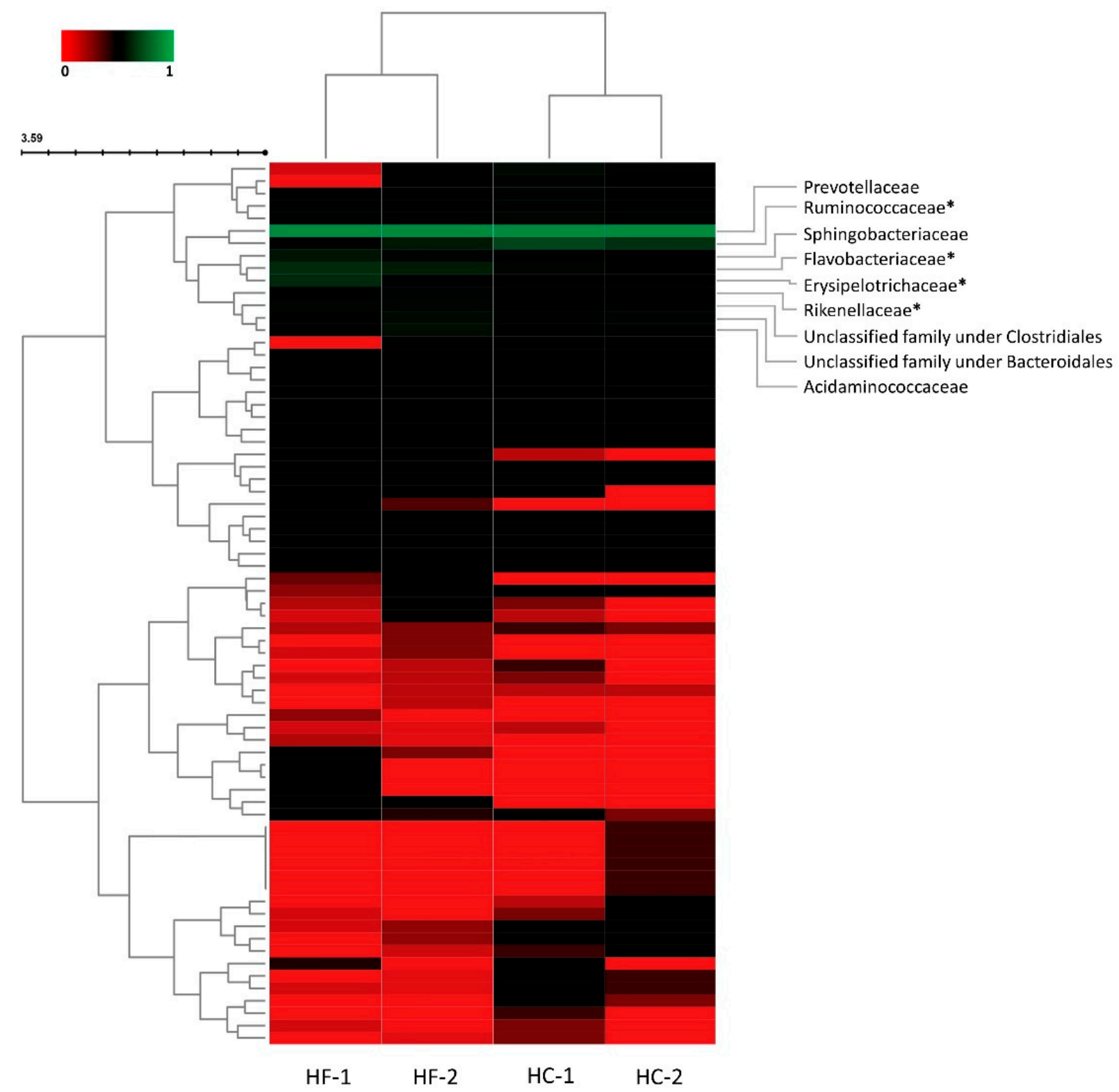

Figure 3. Heatmap clustering of observed families (rows) based on normalized value (0-1) of relative abundance per treatment (columns) using Bray-Curtis dissimilarity test and Ward linkage. Figure generated using Interactive Cluster Heatmap library (InCHlib) [49]. HF-1, high-forage diet; HC-1, high-concentrate diet; HC-2, high-concentrate diet; HF-2, high-forage diet. Asterisk $\left.{ }^{*}\right)$ denotes significant differences $(p<0.05)$.

The boxplot representation of alpha diversity indices is shown in Figure 4. Alpha diversity indices are composite indices that reflect abundance and consistency. The Chao1, which estimates species richness, significantly increased during the high-forage diet $(p=0.025)$, while the opposite was observed when cattle received the high-concentrate diet (Figure 4a). Shannon index, which reflects the diversity of the OTU in samples, presented high-forage diet groups as the most diverse $(p=0.013)$ among treatments, and high-concentrate diet groups as the least (Figure 4b). Moreover, Figure 4c shows the boxplot of OTUs of observed species from the samples. The number of OTUs in both high-forage diet groups were higher (though not significant; $p=0.259$ ) than the other groups. The diversity index is used to analyze the temporal and spatial changes in species composition, which reflects whether bacterial communities between groups have differences. 


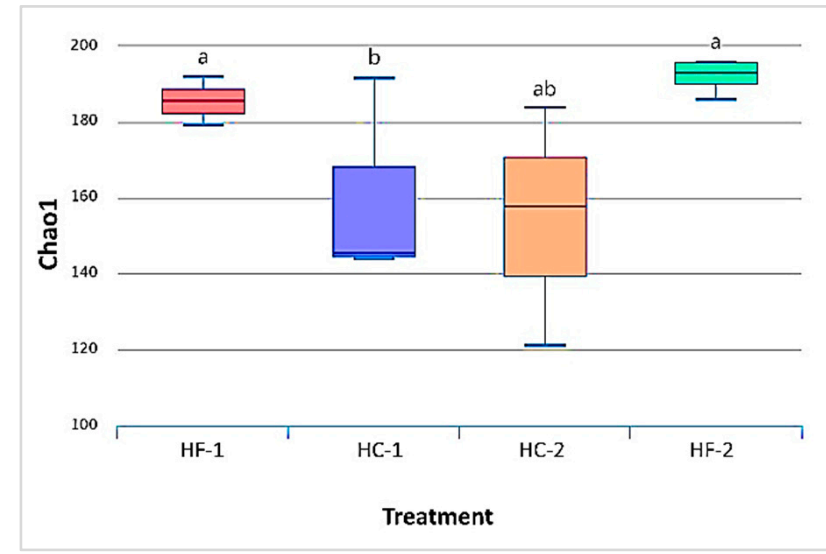

(a)

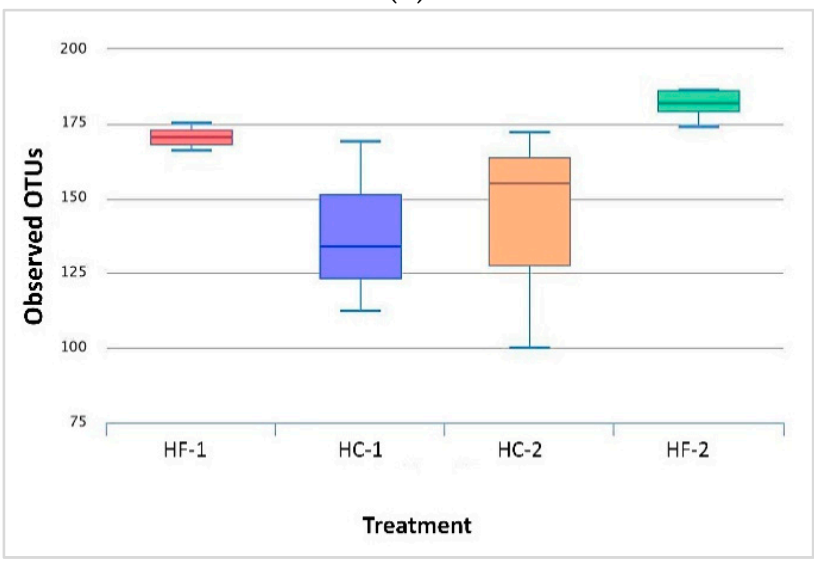

(c)

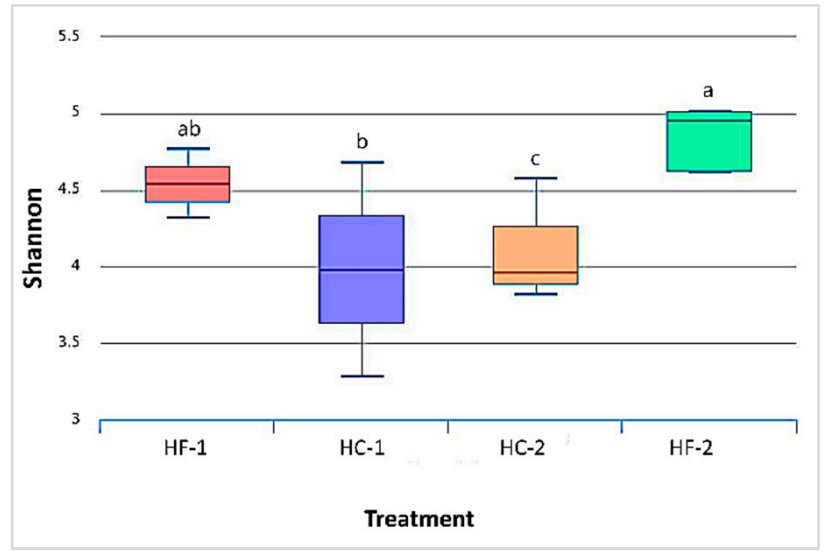

(b)

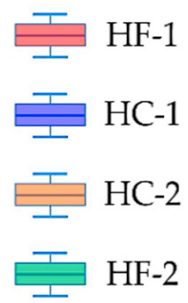

Figure 4. Boxplot representation of alpha diversity indices: (a) chao1, (b) Shannon, and (c) observed OTUs, between diet groups. Alpha-diversity metrics' visualization were done in MetaCOMET [40] and computed using QIIME [39]. HF-1, high-forage diet; HC-1, high-concentrate diet; HC-2, high-concentrate diet; HF-2, high-forage diet. ${ }^{\text {a-c }}$ superscript denotes significant differences $(p<0.05)$.

3.3. Rumen Epithelial Differentially Expressed Genes between Treatments Assigned as the High-Concentrate (Treated Group) and High-Forage (Control Group) Diets

The sequence reads generated per sample ranged from 56,321,752 to 111,981,472 (Table S1). The number of mapped reads also ranged from $65.07 \%$ to $88.32 \%$. Based on the mapped data statistics, the high-concentrate diet group had a greater number of reads than the high-forage diet group. There were 2266 (1120 upregulated and 1146 downregulated), 1494 (769 upregulated and 725 downregulated), and 1719 (899 upregulated and 820 downregulated) differentially expressed genes (DEG) when comparing HC-1, HC-2, and HF-2 groups with the HF-1 (control), respectively (Figure 5). The expression volume was defined as the geometric mean of two groups' expression level. In order to confirm the genes that showed a higher expression difference compared to the control according to expression volume, a volume plot was drawn (Figure 6). It showed a summary of the top expressed genes obtained from the samples between the groups. There were nine top genes obtained after analysis, namely carbonic anhydrase 1, the RNA component of mitochondrial RNA processing endoribonuclease, S100 calcium binding protein A12, keratin 5, keratin 6A, keratin 14, keratin 15, basigin (Ok blood group), and peroxiredoxin 6 . Figure 6a shows the top five expressed genes between the diet groups. Carbonic anhydrase I, the RNA component of mitochondrial RNA processing endoribonuclease, and S100 calcium binding protein A12, were highly expressed in HC-1; however, Keratin 15 and 5 were highly expressed in HF-1 (Table S2). Figure $6 \mathrm{~b}$ shows that the RNA component of the mitochondrial RNA processing endoribonuclease, keratin 14 and 6A, and basigin 
(Ok blood group) were all highly expressed genes in the concentrate-treated group, except keratin 15, which was found to be highly expressed in the control group (Table S3). Meanwhile, the S100 calcium binding protein A12 and peroxiredoxin 6 were both highly expressed in the treated group, while keratin 1, keratin 14, and keratin 15 were highly expressed in the control group (Table S4, Figure 6c). The results of hierarchical clustering are presented in Figure 7, showing the clustering of genes and samples based on expression level (normalized value) from the significant list. The hierarchical clustering between samples showed that HF-1 was of a different cluster, separating HC-1, as well as HC-2 and HF-2, based on gene expression pattern. This evidently showed that transitioning of diet from high-forage to high-concentrate has an almost completely reversed pattern of expressed genes (HF-1 vs. HC-1). However, during HC-2, a different gene expression pattern was observed compared to the previous period of the same diet. Also, even when the diet was reverted back to high-forage, gene expression was different, which presented a more closely related expression pattern with HC-2.

\section{HC-1/HF-1}

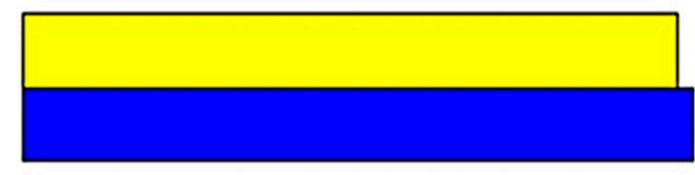

HC-2/HF-1

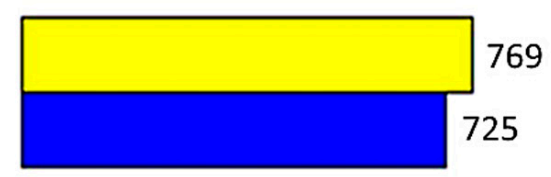

HF2/HF-1

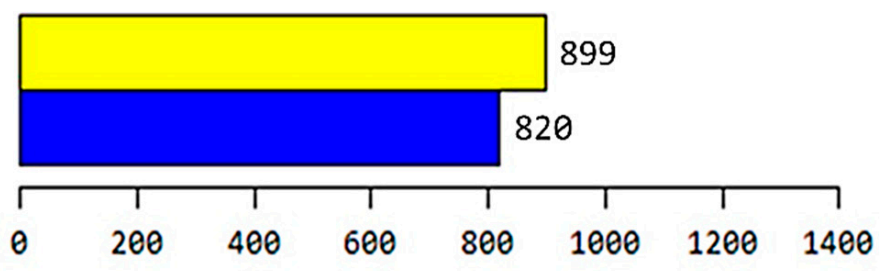

Count of genes

Figure 5. The differentially expressed genes' (DEGs) up- and down-regulated count among HF-1 (control), HC-1, HC-2, and HF-2 groups. The Y-axis represents up- and down-regulation of DEGs between control vs. treatment groups. The $\mathrm{X}$-axis represents the total number of transcripts (DEGs for each pairwise comparison was selected at FC > =2). HF-1, high-forage diet (served as control group); HC-1, high-concentrate diet; HC-2, high-concentrate diet; HF-2, high-forage diet. 


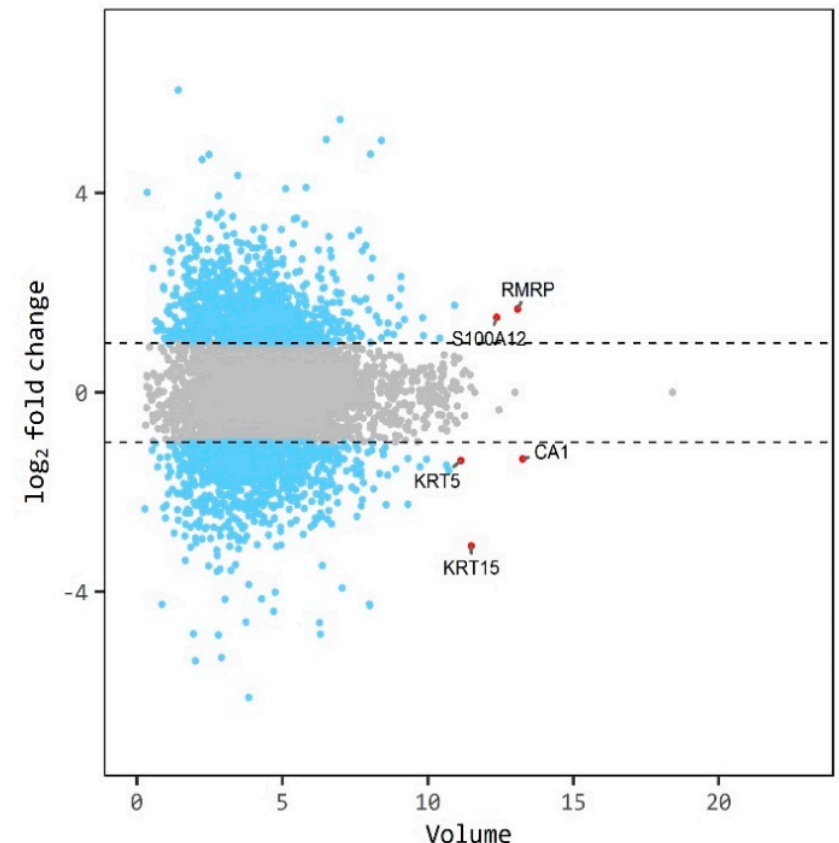

HF-1 vs HC-1

(a)

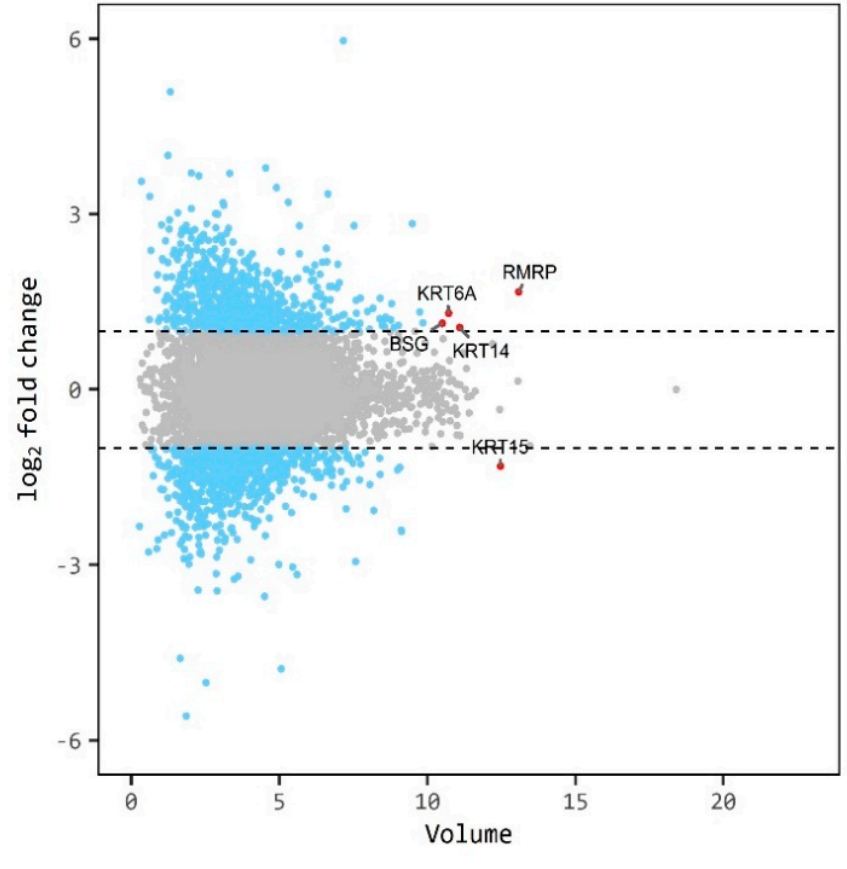

HF-1 vs HC-2

(b)

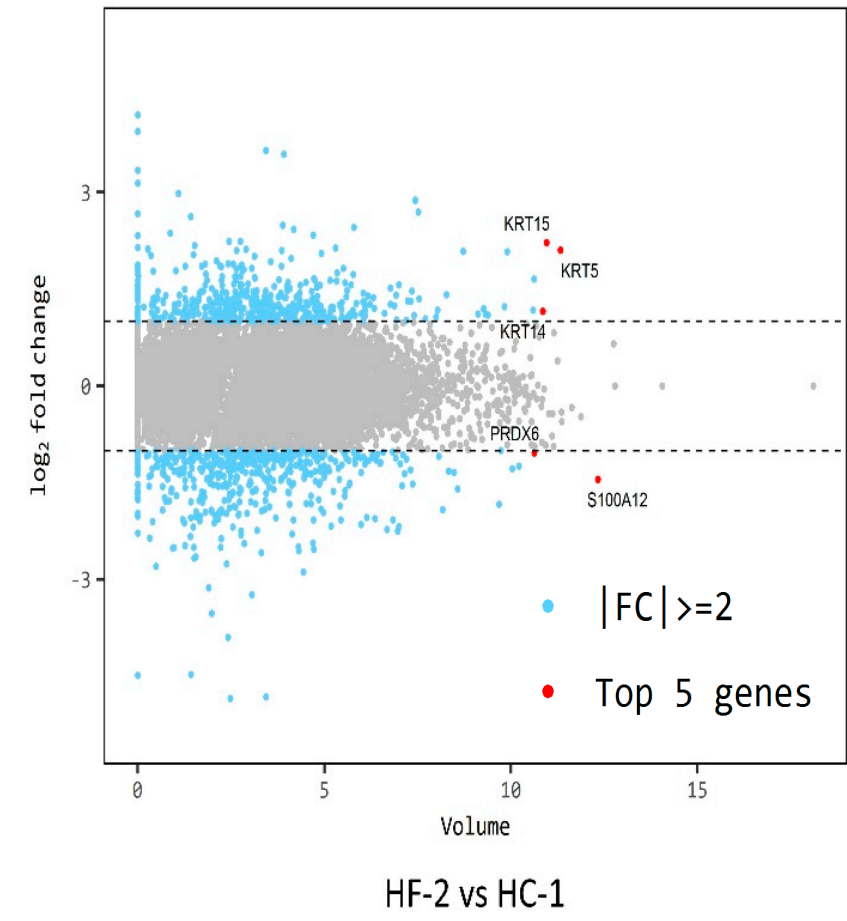

(c)

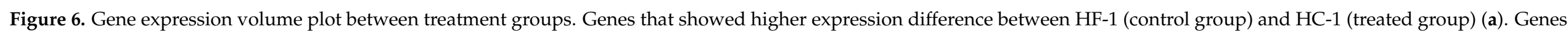

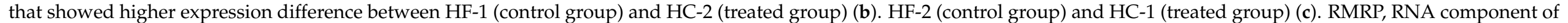

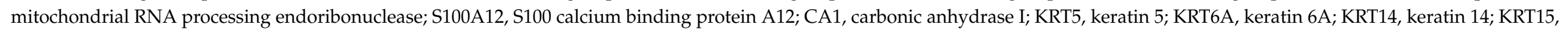
keratin 15; BSG, basigin; PRDX6, peroxiredoxin 6 . Red dot: top 5 genes by volume which satisfies, $\mid$ fc $\mid \geq 2$. FC, fold-change. 


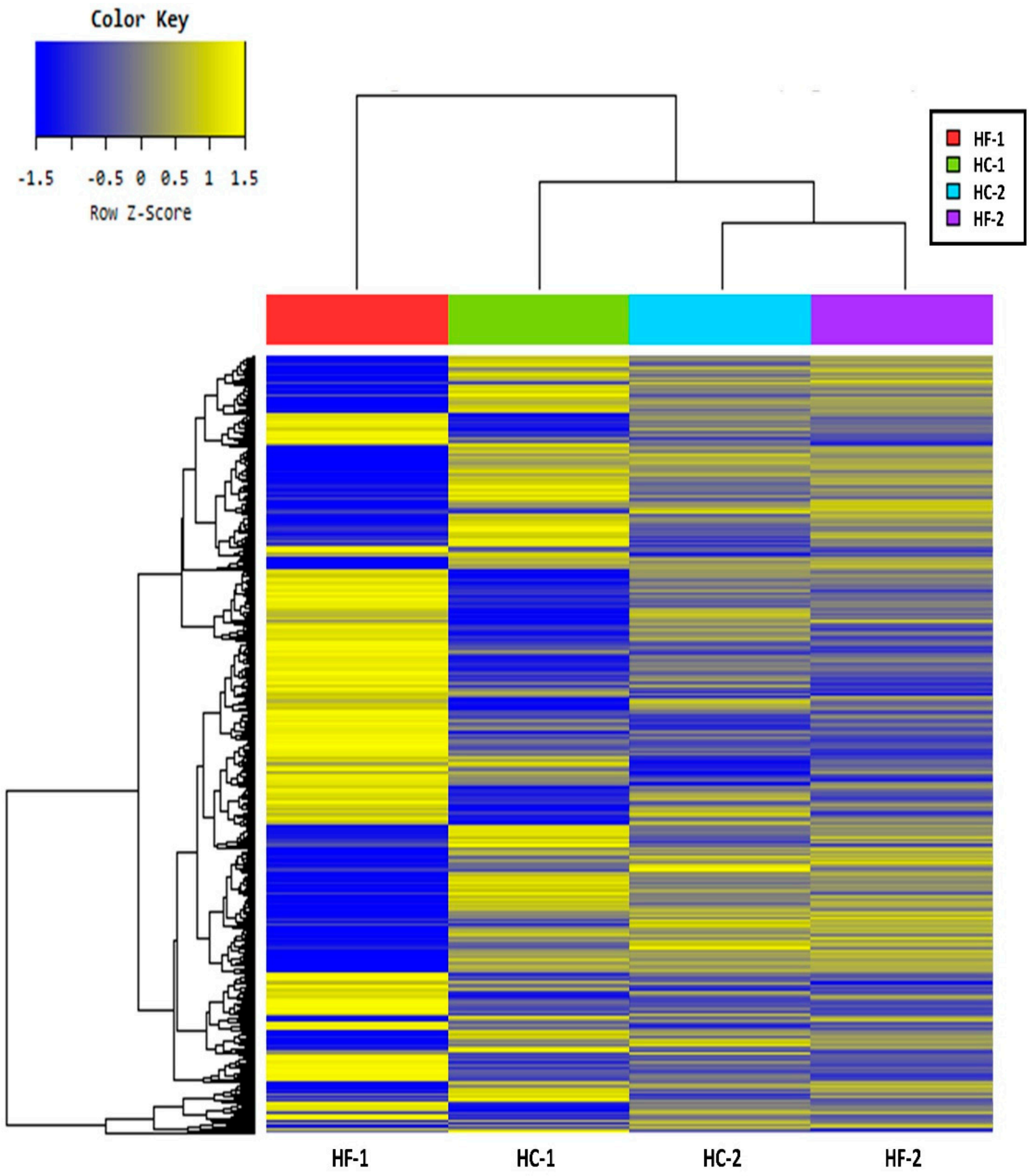

Figure 7. Hierarchical clustering analysis by Euclidean distance and complete linkage showing the similarity of genes and treatments based on normalized value of expression level from the significant list. HF-1, high-forage diet; HC-1, high-concentrate diet; HC-2, high-concentrate diet; HF-2, high-forage diet.

\section{Discussion}

A sudden decline in ruminal $\mathrm{pH}$ is currently one of the major health issues in dairy farming that causes feed intake reduction, digestion problems, and production losses. The prevalence of this mainly affects cattle health and drastically increases management costs. In all ruminants, the rumen is a complex microbial ecosystem and is inhabited by a large density of microbiota, bacteria, anaerobic fungi, archaea, and ciliate protozoa [50]. Rumen microbes have vital roles in the degradation of feedstuffs, and the production 
of VFAs, lipids, amino acids, and hydrogen, which are essential for the maintenance, growth, and production performance of ruminants [51]. These microbes also supply VFAs, proteins, and vitamins to their ruminant hosts through degrading and fermenting feed materials [17]. A better understanding of the rumen microbiome under extensive feeding conditions is essential due to the complexity of the rumen ecosystem, as the manipulation of ruminal microbiota can improve feed efficiency and optimize rumen function [52,53]. Previous studies have demonstrated that changes in rumen microbial communities are affected by several factors, such as ruminant species, age, health, season, geographical location, feed additives, and diet [18,54-56]. Specifically, a diet switch from high forage to high concentrate will definitely cause an enormous change in the rumen bacterial community, which can negatively affect productivity and has the potential to develop metabolic disorders in ruminants [57]. In the present study, we investigated the effect of changing diet on ruminal fermentation characteristics, bacterial community composition, and transcriptome profile of Holstein Friesian cows, which was induced by the transition from a high-forage to a high-concentrate diet, and then returned to a high-forage diet.

Ruminal $\mathrm{pH}$ and its daily fluctuations are considered to be a major factor in the occurrence of SARA and the regulation of microbial activity $[15,58,59]$. Based on the proposed $\mathrm{pH}$ thresholds that define ruminal acidosis, it seemed that the Holstein cows in the present study were in SARA condition during the two successive high-concentrate diet periods. A similar result was obtained from the study conducted by Lee et al. [17], wherein the ruminal $\mathrm{pH}$ of a Holstein cow drastically decreased upon receiving a high-concentrate diet. The chemical composition of the rumen fluid during the transition from hay to high-concentrate diet can be associated with the development of subacute acidosis [57,60]. A ruminant diet with $35 \%$ concentrate reduced the rumen $\mathrm{pH}$ below 5.6 for more than $180 \mathrm{~min} /$ day, which was an indication of acidosis [15,61,62]. Generally, high-concentrate diets increase both lactic acid producers and utilizers, while decreasing the number of fiberdegrading bacteria. The high level of non-structural carbohydrates from a high-concentrate diet resulted in a drastic decrease in $\mathrm{pH}$ of the rumen [63]. Reduction in $\mathrm{pH}$ is due to the rapid fermentation of non-structural carbohydrates, and volatile fatty acid accumulation in the rumen [60]. Consequently, reduced $\mathrm{pH}$ was also a result of the accumulation of lactic acid in the rumen [17,64]. Moreover, Tajima et al. [64] added that once ruminal pH decreased below 5.6, acid-resistant microbes became dominant in the rumen, which can cause metabolic disorders.

A high concentration of VFA was identified during the high-concentrate diet periods of the present study, which is in accordance with the results of Bevans et al. [65], Sato [66], and Nagata et al. [2]. Lee et al. [17] also stated that a reduction in ruminal $\mathrm{pH}$ was directly related to the concentration of total VFA. Previous studies demonstrated that an increase in the VFA concentration, rather than lactate, primarily affected ruminal $\mathrm{pH}$ in response to high-concentrate-feeding in cattle [67]. The result of the study by Tajima et al. [57] showed the total VFA concentration tended to increase when cattle were fed a high-concentrate diet. Moreover, Li et al. [15] added that the increase in the concentration of total VFA and the molar proportion of propionate was an indication of a large amount of starch, which usually occurs during the SARA condition. A typical response to an acidotic-like condition in the rumen is changes in the relative proportion of VFA $[29,60]$. The high concentration of butyrate in the high-concentrate diet period of the current study is also in agreement with the result of Wang et al. [68] and was consistent with that of Ribeiro et al. [69]. Similar to the present study, high propionate concentration in the rumen of cows fed a high-concentrate compared with a high-forage diet has been reported in the literature [70]. Greater propionate production might trigger gluconeogenesis and milk production response [71]. Meanwhile, acetate and butyrate can be converted into each other in the rumen [68]. According to a previous study, 28\% of acetate is not absorbed by the rumen in the form of acetate [72] and microorganisms can use this to produce butyrate by acetyl-Coenzyme A transferase and/or butyryl-Coenzyme A transferase [73]. Rumen microbes can promote the metabolism of microorganisms through the energy 
dissipation process and convert acetate to butyrate continuously during a high-concentrate diet period [73]. Additionally, the present study also supports the claim of Nagata et al. [2], who identified a concurrent increase in the total VFA and $\mathrm{NH}_{3}-\mathrm{N}$ concentrations during the high-concentrate feeding period. Lana et al. [74] reported that forage- and concentrate-fed cattle had various populations of ammonia-producing bacteria in rumen; thus, the optimal ammonia concentration in rumen fluid resulted in the production of microbial protein and the maximum fermentation rate. $\mathrm{An} \mathrm{NH}_{3}-\mathrm{N}$ concentration higher than $5 \mathrm{mg} / \mathrm{L}$ is the minimum requirement for maximal microbial growth and indicates that a high-concentrate diet can produce a large amount of ruminal microbial crude protein for utilization by the animals [75]. Moreover, the increased $\mathrm{NH}_{3}-\mathrm{N}$ concentration is indicative of an increased rate of proteolysis and amino acid metabolism in the animals [76].

In concordance with many previous studies, the transition of a diet from high forage to high concentrate resulted in various changes in the condition and substrate availabilities in the rumen, which further reduced the richness and diversity of ruminal fluid microbiota [77-80]. Reports from many studies showed that concentrate-feeding and concentrateinduced SARA alter microbial community structures in the digestive tract $[29,30,79]$. Ruminant dietary changes contributed significant impacts on rumen bacterial communities $[64,81,82]$. A previous study demonstrated that dietary forage to concentrate ratio increased from 80:20 to 20:80, and distinctly changed the rumen bacterial population structure [79]. Both studies of Ogata et al. [83,84] presented that low ruminal $\mathrm{pH}$ decreased bacterial richness and diversity. During acidosis challenge induced by feeding a concentrate diet, the low ruminal $\mathrm{pH}$ could lead to the death and lysis of bacteria, resulting in low relative abundances [84]. The metagenomics survey of bacterial community composition in the present study agreed with previous research showing Firmicutes and Bacteroidetes as the most common phyla in the rumen $[29,77,78]$. Furthermore, those studies stated that the high-concentrate diet of cattle increased the relative abundance of Firmicutes, while decreasing the abundance of Bacteroidetes. Petri et al. [77] and Henderson et al. [54] also stated that Firmicutes and Bacteroidetes were both identified as the core rumen microbiome. This statement suggests that these two phyla may be less affected by rumen environment changes due to acidic challenges or dietary changes. Excessive grain feeding reduces richness and diversity of rumen microbiota, resulting in a relative abundance reduction of Bacteroidetes and an increase of Firmicutes in the rumen [77,78,85]. Studies have shown that the low proportion of Bacteroidetes during the high-concentrate diet period was due to high acidity in the rumen [66,78]. Meanwhile, Kaoutari et al. [86] concluded that Bacteroidetes was more efficient at degrading structural carbohydrates than Firmicutes. Moreover, the utilization of dietary fiber leads to an increased abundance of Firmicutes rather than Bacteroidetes. Henderson et al. [54] stated that the most dominant taxa in the rumen were the genera Prevotella, a well-known degrader of starch, $\beta$ glycans, protein, pectin, and hemicellulose, and Ruminococcus, a cellulose degrader. This statement on the abundance of Prevotella was in accordance with the microbiome result of the present study. The ability of this genus to use a variety of substrates allows it to dominate in the rumen under a range of diets [87]. Furthermore, Prevotella species are prominent ruminal proteolytic bacteria which produce a variety of extracellular degradative enzymes [88], while Ruminococcus are specialized amylolytic bacteria known for the degradation of celluloses in the rumen [89]. Prevotella ruminicola appeared to be the predominating species in the present study. It is one of the most numerous groups recovered from the rumen and plays a role in degradation of polysaccharides [90-92]. The increase in abundance of Prevotella marshii and Prevotella jejuni during the high-concentrate diet condition might be due to its cell function as saccharolytic and its ability to ferment glucose [93]. On the other hand, the high prevalence of Prevotella oralis under the high-forage condition was likely due to their utilizing function on a wide variety of polysaccharides, and they are thought to be essential contributors to the degradation of xylan [94-98]. Whitehead [99] emphasized that Prevotella species in the rumen could contribute to cell wall degradation through synergistic interactions with various species of cellulolytic bacteria. Moreover, the 
research of Ntougias et al. [100] revealed that Olivibacter sitiensis is a xylanolytic bacterium which is involved in the cleavage of $\beta-1,4$-xylosic bonds in hemicelluloses. This statement supported the abundance of $O$. sitiensis in the present study, which is also observed during a high-forage diet condition. The significant increase in abundance of Galbibacter mesophilus and Erysipelothrix larvae in the high-forage diet was likely due to its capability to utilize celluloses, which is an important role in regulating the host's metabolism, thus promoting efficient degradation of polysaccharides [101,102]. Although Ruminococcus is a well-known cellulolytic bacterium, several species, such as $R$. bromii, are capable of fermenting starch $[103,104]$. This may explain the abundance of $R$. bromii in the present study. Succiniclasticum are known to ferment succinate and convert it to propionate $[51,79,105]$. The abundance of Succiniclasticum ruminis in the high-concentrate diet periods might explain the high propionate concentration in the rumen. There are also some bacterial species which were found with lower abundance (not presented in figures) that have been reported to exhibit an essential role in pivotal rumen function as rumen homeostasis index due to their contribution in reducing sulfate and its metabolic flexibility [106]. Published studies have shown that this species has the ability to ferment and convert succinate to propionate, which is an essential precursor of glucose in ruminants [105].

In the present study, sufficient information was provided on the differential gene expression pattern in rumen epithelial tissue's response to the adverse effect of diet transition from a two-week high-forage diet, to a four-week acidosis challenge, back to a two-week high-forage diet. Apart from short-chain fatty acid metabolism, nutrient absorption and transportation are critical functions of the ruminal epithelium [35,107-109]. Rumen epithelial structure development is attributed to VFA absorption; thus, the excessive amount of VFA can lead to a reduction in $\mathrm{pH}$ that can damage the ruminal epithelium $[108,110,111]$. Moreover, a high-starch diet in ruminants can cause SARA, which may lead to the destruction of the rumen epithelial tissue in the long term [61,107]. Steele et al. [12] demonstrated that a significant reduction of the total epithelium depth occurred when using a highconcentrate diet-induced acidosis model. In a recent study of Li et al. [35], where cattle were subjected to rumen acidosis by feeding a high-starch diet, the rumen epithelial transcriptome showed a high number of genes that were differentially expressed, impacting biological pathways, specifically genes responsible for cell signaling and morphogenesis. The two assigned groups in the present study had nine major expressed genes, which were confirmed by the high expression difference through the expression volume plot. The high expression of carbonic anhydrase I (CAI) in the high-concentrate-feeding period was in agreement with the results of previous studies [112,113]. They stated that CAI catalyzed the rapid hydration and dehydration of $\mathrm{CO}_{2}$ and $\mathrm{H}_{2} \mathrm{CO}_{3}$, respectively. It also played essential roles in physiological systems, such as acid-based balance, respiration, bone resorption, ion transport, ureagenesis, lipogenesis, and gluconeogenesis. Moreover, it secreted parotid saliva containing a $\mathrm{HCO}_{3}{ }^{-}$-rich alkaline solution, which helped maintain the rumen $\mathrm{pH}$ in the range of 6-7 [112]. Meanwhile, the S100 calcium binding protein A12 (S100A12) is an important mediator in various cellular functions which involve apoptosis, cell proliferation, inflammation, and immunity, and is known to be associated with innate immune responses [114-116]. This may explain its high expression in the highconcentrate-feeding period, given the fact that these cattle were under SARA conditions, which has been associated with the inflammation of different tissues and organs of dairy cattle $[58,110,117]$. The high expression volume of the gene responsible for the release of keratin in the high-forage feeding period was supported by the results of previous research [118-120]. Keratin is known as the epithelial-specific member of the intermediate filament genes and proteins family, which is responsible for structural support and the regulation of metabolic processes [118]. Fiber-diet-fed ruminants were associated with hard keratins in their epithelium [119]. In a previous report on gene expression, Xiang et al. [120] stated that sheep fed different quality fibrous diets had full-thickness rumen wall tissue due to the keratin produced. The stratified squamous epithelium of the rumen surface was cornified and keratinized to protect it from physical damage caused by ingested plant 
material [121]. Basigin (BSG), also called CD147 or extracellular matrix metalloproteinase inducer (EMMPRIN), is a transmembrane protein that belongs to the immunoglobulin superfamily and is involved in various pathological and physiological phenomena. It is associated with several proteins, including monocarboxylate transporters (MCTs), which catalyze the proto-linked transport of monocarboxylates such as lactate, pyruvate, and ketone bodies, across the plasma membrane [122]. This protein also facilitates the transport of metabolites from the rumen epithelium to the blood $[123,124]$ and possesses an essential role in rumen $\mathrm{pH}$ regulation [125-128]. These data on BSG support the results of the present study. Furthermore, the high expression volume of peroxiredoxin 6 (PRDX6) in our study was in accordance with previous research [129,130]. Hollmann et al. [129] observed that the expression of PRDX6 was downregulated in high-energy diet-fed animals. Meanwhile, Bondzio et al. [130] described PRDX6 as an important antioxidant enzyme that protects cells against oxidative injury by the reduction of endogenous levels of peroxides. This enzyme might also be involved in maintaining cellular homeostasis in the rumen epithelium during concentrate-supplemented diet adaptation. The comparative analysis of the transcriptome profiles revealed that changing the diet can alter rumen epithelia gene expression [131]. The gene expression pattern in epithelial tissue of the rumen was drastically affected as a result of diet transition. Although, the diet was reverted back to high-forage, the hierarchical clustering of HF-2 based on DEG pattern was more related to the patterns during the acidosis period, which could imply that these harsh changes on the transcriptome of rumen epithelium would require more time to recover to the normal gene expression pattern. Hence, analysis of DEG using RNA sequencing in an extended period of high-forage diet after acidosis challenge is recommended to assess how long would it take for the animals to recover their normal gene expression pattern.

\section{Conclusions}

Ruminal fermentation characteristics, the rumen bacterial community structure, and differentially expressed genes were affected by the changing diet and were induced by transition from a high-forage to a high-concentrate diet. Ruminal $\mathrm{pH}$ drastically decreased during the high-concentrate diet period, while a greater increase in concentrations of $\mathrm{NH}_{3}$ $\mathrm{N}$ and individual and total VFAs were observed. This study was able to confirm the changes in the rumen bacterial community and structure. Among the diets, the high-concentrate diet reduced the richness and diversity of the rumen microbiota. The metagenomics survey on bacterial abundance revealed that Bacteroidetes dominated all the treatments at the phylum level. Prevotella abundance significantly differed between the high-forage and high-concentrate diet periods and had a higher relative abundance among the microbial genera. Besides degrading starch, $\beta$ glycans, protein, pectin, and hemicellulose, they also have the ability to use a variety of substrates, allowing them to dominate the rumen under a range of diets. Meanwhile, there were nine top expressed genes that satisfied the twofold change based on the expression volume analysis. The differentially expressed genes' analysis revealed that changing diet can alter gene expression in the rumen epithelia.

Supplementary Materials: The following are available online at https:/ / www.mdpi.com/2076-2 615/11/3/838/s1, Table S1: Mapped cDNA fragments obtained from RNA sequencing, Table S2: Top five expressed genes between HF-1 (control group) and HC-1 (treated group), Table S3: Top five expressed genes between HF-1 (control group) and HC-2 (treated group), Table S4: Top five expressed genes between HF-2 (control group) and HC-1 (treated group), Figure S1: Heatmap showing the relationship of bacterial species on $\mathrm{pH}$ values of treatments based on Pearson correlation.

Author Contributions: Conceptualization, S.S.L. (Sang Suk Lee), C.D.J. and S.C.R.; supervision, S.S.L. (Sang Suk Lee); experiment, S.C.R. and C.D.J.; data curation, S.C.R. and C.D.J.; formal analysis, S.C.R., C.D.J. and S.S.L. (Sang Suk Lee); laboratory analysis, S.C.R.; methodology, S.C.R., C.D.J. and S.S.L. (Sang Suk Lee); software, S.H.K. (Seon Ho Kim), E.T.K., S.S.L. (Sung Sill Lee) and Y.I.C.; validation, S.S.L. (Sang Suk Lee); investigation, S.C.R., C.D.J. and S.S.L. (Sang Suk Lee); writing-original draft, S.S.L. (Sang Suk Lee), C.D.J. and S.C.R.; writing-review and editing: S.C.R., L.L.M., S.S.L. (Seung 
Ha Kang) and S.S.L. (Sang Suk Lee). All authors have read and agreed to the published version of the manuscript.

Funding: This research was funded by the National Research Foundation of Korea (NRF), Republic of Korea, project no. 2020R1I1A3074048.

Institutional Review Board Statement: The present study was approved by the Ethics Committee on Animal Use of Sunchon National University under approval number SCNU IACUC-2008-01.

Informed Consent Statement: Not applicable.

Data Availability Statement: The data presented in this study are available on request from the corresponding author.

Conflicts of Interest: The authors declare no conflict of interest.

\section{References}

1. Wetzels, S.; Mann, E.; Pourazad, P.; Qumar, M.; Pinior, B.; Metzler-Zebeli, B.; Wagner, M.; Schmitz-Esser, S.; Zebeli, Q. Epimural bacterial community structure in the rumen of Holstein cows with different responses to a long-term subacute ruminal acidosis diet challenge. J. Dairy Sci. 2017, 100, 1829-1844. [CrossRef]

2. Nagata, R.; Kim, Y.-H.; Ohkubo, A.; Kushibiki, S.; Ichijo, T.; Sato, S. Effects of repeated subacute ruminal acidosis challenges on the adaptation of the rumen bacterial community in Holstein bulls. J. Dairy Sci. 2018, 101, 4424-4436. [CrossRef]

3. Zebeli, Q.; Aschenbach, J.; Tafaj, M.; Boguhn, J.; Ametaj, B.; Drochner, W. Invited review: Role of physically effective fiber and estimation of dietary fiber adequacy in high-producing dairy cattle. J. Dairy Sci. 2012, 95, 1041-1056. [CrossRef]

4. Boerman, J.; Potts, S.; VandeHaar, M.; Allen, M.; Lock, A. Milk production responses to a change in dietary starch concentration vary by production level in dairy cattle. J. Dairy Sci. 2015, 98, 4698-4706. [CrossRef] [PubMed]

5. Kleen, J.; Cannizzo, C. Incidence, prevalence and impact of SARA in dairy herds. Anim. Feed Sci. Technol. 2012, 172, 4-8. [CrossRef]

6. Kleen, J.; Hooijer, G.; Rehage, J.; Noordhuizen, J. Subacute ruminal acidosis (SARA): A review. J. Vet. Med. Ser. A 2003, 50, 406-414. [CrossRef] [PubMed]

7. Hernández, J.; Benedito, J.L.; Abuelo, A.; Castillo, C. Ruminal Acidosis in Feedlot: From Aetiology to Prevention. Sci. World J. 2014, 2014, 1-8. [CrossRef] [PubMed]

8. Owens, F.N.; Secrist, D.S.; Hill, W.J.; Gill, D.R. Acidosis in cattle: A review. J. Anim. Sci. 1998, 76, 275-286. [CrossRef] [PubMed]

9. Rabelo, E.; Rezende, R.; Bertics, S.; Grummer, R. Effects of Transition Diets Varying in Dietary Energy Density on Lactation Performance and Ruminal Parameters of Dairy Cows. J. Dairy Sci. 2003, 86, 916-925. [CrossRef]

10. Nagaraja, T.G.; Titgemeyer, E.C. Ruminal acidosis in beef cattle: The current microbiological and nutritional outlook. J. Dairy Sci. 2007, 90, E17-E38. [CrossRef] [PubMed]

11. Zebeli, Q.; Metzler-Zebeli, B.U. Interplay between rumen digestive disorders and diet-induced inflammation in dairy cattle. Res. Vet. Sci. 2012, 93, 1099-1108. [CrossRef] [PubMed]

12. Steele, M.A.; Croom, J.; Kahler, M.; AlZahal, O.; Hook, S.E.; Plaizier, K.; McBride, B.W. Bovine rumen epithelium undergoes rapid structural adaptations during grain-induced subacute ruminal acidosis. Am. J. Physiol. Integr. Comp. Physiol. 2011, 300, R1515-R1523. [CrossRef]

13. Osborne, J.; Mutsvangwa, T.; AlZahal, O.; Duffield, T.; Bagg, R.; Dick, P.; Vessie, G.; McBride, B. Effects of Monensin on Ruminal Forage Degradability and Total Tract Diet Digestibility in Lactating Dairy Cows During Grain-Induced Subacute Ruminal Acidosis. J. Dairy Sci. 2004, 87, 1840-1847. [CrossRef]

14. Grant, R.; Mertens, D. Influence of Buffer $\mathrm{pH}$ and Raw Corn Starch Addition on In Vitro Fiber Digestion Kinetics. J. Dairy Sci. 1992, 75, 2762-2768. [CrossRef]

15. Li, F.; Cao, Y.; Liu, N.; Yang, X.; Yao, J.; Yan, D. Subacute ruminal acidosis challenge changed in situ degradability of feedstuffs in dairy goats. J. Dairy Sci. 2014, 97, 5101-5109. [CrossRef]

16. Russell, J.B.; Wilson, D.B. Why Are Ruminal Cellulolytic Bacteria Unable to Digest Cellulose at Low pH? J. Dairy Sci. 1996, 79, 1503-1509. [CrossRef]

17. Lee, M.; Jeong, S.; Seo, J.; Seo, S. Changes in the ruminal fermentation and bacterial community structure by a sudden change to a high-concentrate diet in Korean domestic ruminants. Asian-Australas. J. Anim. Sci. 2019, 32, 92-102. [CrossRef]

18. Russell, J.B. Rumen Microbiology and Its Role in Ruminant Nutrition; Department of Microbiology, Cornell University: Ithaca, NY, USA, 2002.

19. Fan, Q.; Wanapat, M.; Yan, T.; Hou, F. Altitude influences microbial diversity and herbage fermentation in the rumen of yaks. BMC Microbiol. 2020, 20, 1-13. [CrossRef]

20. Zhou, Z.; Fang, L.; Meng, Q.; Li, S.; Chai, S.; Liu, S.; Schonewille, J.T. Assessment of Ruminal Bacterial and Archaeal Community Structure in Yak (Bos grunniens). Front. Microbiol. 2017, 8, 179. [CrossRef] 
21. Lettat, A.; Nozière, P.; Silberberg, M.; Morgavi, D.P.; Berger, C.; Martin, C. Rumen microbial and fermentation characteristics are affected differently by bacterial probiotic supplementation during induced lactic and subacute acidosis in sheep. BMC Microbiol. 2012, 12, 142. [CrossRef] [PubMed]

22. Liu, C.; Wu, H.; Liu, S.; Chai, S.; Meng, Q.; Zhou, Z. Dynamic Alterations in Yak Rumen Bacteria Community and Metabolome Characteristics in Response to Feed Type. Front. Microbiol. 2019, 10, 1116. [CrossRef]

23. Bandarupalli, V.V.K.; St-Pierre, B. Identification of a Candidate Starch Utilizing Strain of Prevotella albensis from Bovine Rumen. Microorganisms 2020, 8, 2005. [CrossRef]

24. Nafikov, R.A.; Beitz, D.C. Carbohydrate and Lipid Metabolism in Farm Animals. J. Nutr. 2007, 137, 702-705. [CrossRef] [PubMed]

25. Huntington, G.B.; Harmon, D.L.; Richards, C.J. Sites, rates, and limits of starch digestion and glucose metabolism in growing cattle1. J. Anim. Sci. 2006, 84, E14-E24. [CrossRef] [PubMed]

26. Huntington, G.B. Starch utilization by ruminants: From basics to the bunk. J. Anim. Sci. 1997, 75, 852-867. [CrossRef]

27. Owens, F.N.; Zinn, R.A.; Kim, Y.K. Limits to Starch Digestion in the Ruminant Small Intestine1,2. J. Anim. Sci. 1986, 63, 1634-1648. [CrossRef]

28. Mills, J.A.N.; France, J.; Dijkstra, J. A review of starch digestion in the lactating dairy cow and proposals for a mechanistic model: Dietary starch characterisation and ruminal starch digestion. J. Anim. Feed Sci. 1999, 8, 291-340. [CrossRef]

29. Khafipour, E.; Li, S.; Plaizier, J.C.; Krause, D.O. Rumen Microbiome Composition Determined Using Two Nutritional Models of Subacute Ruminal Acidosis. Appl. Environ. Microbiol. 2009, 75, 7115-7124. [CrossRef]

30. Hook, S.E.; Steele, M.A.; Northwood, K.S.; Dijkstra, J.; France, J.; Wright, A.-D.G.; McBride, B.W. Impact of subacute ruminal acidosis (SARA) adaptation and recovery on the density and diversity of bacteria in the rumen of dairy cows. FEMS Microbiol. Ecol. 2011, 78, 275-284. [CrossRef]

31. Li, S.; Khafipour, E.; Krause, D.; Kroeker, A.; Rodriguez-Lecompte, J.; Gozho, G.; Plaizier, J. Effects of subacute ruminal acidosis challenges on fermentation and endotoxins in the rumen and hindgut of dairy cows. J. Dairy Sci. 2012, 95, 294-303. [CrossRef]

32. Stark, R.; Grzelak, M.; Hadfield, J. RNA sequencing: The teenage years. Nat. Rev. Genet. 2019, 20, 631-656. [CrossRef] [PubMed]

33. Bashiardes, S.; Zilberman-Schapira, G.; Elinav, E. Use of Metatranscriptomics in Microbiome Research. Bioinform. Biol. Insights 2016, 10, BBI-S34610. [CrossRef]

34. Ogunade, I.; Pech-Cervantes, A.; Schweickart, H. Metatranscriptomic Analysis of Sub-Acute Ruminal Acidosis in Beef Cattle. Animals 2019, 9, 232. [CrossRef]

35. Li, W.; Gelsinger, S.; Edwards, A.; Riehle, C.; Koch, D. Transcriptome analysis of rumen epithelium and meta-transcriptome analysis of rumen epimural microbial community in young calves with feed induced acidosis. Sci. Rep. 2019, 9, 4744. [CrossRef]

36. Chaney, A.L.; Marbach, E.P. Modified Reagents for Determination of Urea and Ammonia. Clin. Chem. 1962, 8, 130-132. [CrossRef] [PubMed]

37. Soriano, A.P.; Mamuad, L.L.; Kim, S.-H.; Choi, Y.J.; Jeong, C.D.; Bae, G.S.; Chang, M.B.; Lee, S.S. Effect of Lactobacillus mucosae on In vitro Rumen Fermentation Characteristics of Dried Brewers Grain, Methane Production and Bacterial Diversity. Asian-Australas. J. Anim. Sci. 2014, 27, 1562-1570. [CrossRef]

38. Li, W.; Fu, L.; Niu, B.; Wu, S.; Wooley, J. Ultrafast clustering algorithms for metagenomic sequence analysis. Brief. Bioinform. 2012, 13, 656-668. [CrossRef] [PubMed]

39. Caporaso, J.G.; Kuczynski, J.; Stombaugh, J.; Bittinger, K.; Bushman, F.D.; Costello, E.K.; Fierer, N.; Peña, A.G.; Goodrich, J.K.; Gordon, J.I.; et al. Correspondence QIIME allows analysis of high- throughput community sequencing data Intensity normal-ization improves color calling in SOLiD sequencing. Nat. Publ. Gr. 2010, 7, 335-336. [CrossRef]

40. Wang, Y.; Xu, L.; Gu, Y.Q.; Coleman-Derr, D. MetaCoMET: A web platform for discovery and visualization of the core microbiome. Bioinformatics 2016, 32, 3469-3470. [CrossRef]

41. McDonald, D.; Clemente, J.C.; Kuczynski, J.; Rideout, J.R.; Stombaugh, J.; Wendel, D.; Wilke, A.; Huse, S.; Hufnagle, J.; Meyer, F.; et al. The Biological Observation Matrix (BIOM) format or: How I learned to stop worrying and love the ome-ome. GigaScience 2012, 1, 7. [CrossRef]

42. Schloss, P.D.; Westcott, S.L.; Ryabin, T.; Hall, J.R.; Hartmann, M.; Hollister, E.B.; Lesniewski, R.A.; Oakley, B.B.; Parks, D.H.; Robinson, C.J.; et al. Introducing mothur: Open-Source, Platform-Independent, Community-Supported Software for Describing and Comparing Microbial Communities. Appl. Environ. Microbiol. 2009, 75, 7537-7541. [CrossRef] [PubMed]

43. Bolger, A.M.; Lohse, M.; Usadel, B. Trimmomatic: A flexible trimmer for Illumina sequence data. Bioinformatics 2014, 30, 2114-2120. [CrossRef] [PubMed]

44. Kim, D.; Paggi, J.M.; Park, C.; Bennett, C.; Salzberg, S.L. Graph-based genome alignment and genotyping with HISAT2 and HISAT-genotype. Nat. Biotechnol. 2019, 37, 907-915. [CrossRef]

45. Langmead, B.; Salzberg, S.L. Fast gapped-read alignment with Bowtie 2. Nat. Methods 2012, 9, 357-359. [CrossRef] [PubMed]

46. Pertea, M.; Pertea, G.M.; Antonescu, C.M.; Chang, T.-C.; Mendell, J.T.; Salzberg, S.L. StringTie enables improved reconstruction of a transcriptome from RNA-seq reads. Nat. Biotechnol. 2015, 33, 290-295. [CrossRef]

47. Bardou, P.; Mariette, J.; Escudié, F.; Djemiel, C.; Klopp, C. jvenn: An interactive Venn diagram viewer. BMC Bioinform. 2014, 15, 1-7. [CrossRef]

48. Vázquez-Baeza, Y.; Pirrung, M.; Gonzalez, A.; Knight, R. EMPeror: A tool for visualizing high-throughput microbial community data. GigaScience 2013, 2, 16. [CrossRef]

49. Škuta, C.; Bartůněk, P.; Svozil, D. InCHlib_-Interactive cluster heatmap for web applications. J. Chemin. 2014, 6, 1-9. [CrossRef] 
50. Zhang, J.; Shi, H.; Wang, Y.; Li, S.; Cao, Z.; Yajing, W.; He, Y.; Zhang, H. Effect of Dietary Forage to Concentrate Ratios on Dynamic Profile Changes and Interactions of Ruminal Microbiota and Metabolites in Holstein Heifers. Front. Microbiol. 2017, 8, 2206. [CrossRef] [PubMed]

51. Ben Shabat, S.K.; Sasson, G.; Doron-Faigenboim, A.; Durman, T.; Yaacoby, S.; Miller, M.E.B.; White, B.A.; Shterzer, N.; Mizrahi, I. Specific microbiome-dependent mechanisms underlie the energy harvest efficiency of ruminants. ISME J. 2016, 10, $2958-2972$. [CrossRef]

52. Jami, E.; Mizrahi, I. Composition and Similarity of Bovine Rumen Microbiota across Individual Animals. PLoS ONE 2012, 7, e33306. [CrossRef]

53. Bannink, A.; Van Lingen, H.J.; Ellis, J.L.; France, J.; Dijkstra, J. The Contribution of Mathematical Modeling to Understanding Dynamic Aspects of Rumen Metabolism. Front. Microbiol. 2016, 7, 1820. [CrossRef] [PubMed]

54. Henderson, G.; Global Rumen Census Collaborators; Cox, F.; Ganesh, S.; Jonker, A.; Young, W.; Janssen, P.H.; Abecia, L.; Angarita, E.; Aravena, P.; et al. Rumen microbial community composition varies with diet and host, but a core microbiome is found across a wide geographical range. Sci. Rep. 2015, 5, 14567. [CrossRef] [PubMed]

55. Nie, Y.; Zhou, Z.; Guan, J.; Xia, B.; Luo, X.; Yang, Y.; Fu, Y.; Sun, Q. Dynamic changes of yak (Bos grunniens) gut microbiota during growth revealed by polymerase chain reaction-denaturing gradient gel electrophoresis and metagenomics. Asian-Australas. J. Anim. Sci. 2017, 30, 957-966. [CrossRef] [PubMed]

56. Zhan, J.; Liu, M.; Wu, C.; Su, X.; Zhan, K.; Zhao, G.Q. Effects of alfalfa flavonoids extract on the microbial flora of dairy cow rumen. Asian-Australas. J. Anim. Sci. 2017, 30, 1261-1269. [CrossRef]

57. Tajimaa, K.; Araib, S.; Ogataa, K.; Nagaminea, T.; Matsuia, H.; Nakamuraa, M.; Aminov, R.I.; Bennoad, Y. Rumen Bacterial Community Transition During Adaptation to High-grain Diet. Anaerobe 2000, 6, 273-284. [CrossRef]

58. Plaizier, J.; Krause, D.; Gozho, G.; McBride, B. Subacute ruminal acidosis in dairy cows: The physiological causes, incidence and consequences. Vet. J. 2008, 176, 21-31. [CrossRef]

59. Lechartier, C.; Peyraud, J.-L. The effects of starch and rapidly degradable dry matter from concentrate on ruminal digestion in dairy cows fed corn silage-based diets with fixed forage proportion. J. Dairy Sci. 2011, 94, 2440-2454. [CrossRef] [PubMed]

60. Goad, D.W.; Goad, C.L.; Nagaraja, T.G. Ruminal microbial and fermentative changes associated with experimentally induced subacute acidosis in steers. J. Anim. Sci. 1998, 76, 234-241. [CrossRef]

61. Gozho, G.N.; Plaizier, J.C.; Krause, D.O.; Kennedy, A.D.; Wittenberg, K.M. Subacute Ruminal Acidosis Induces Ruminal Lipopolysaccharide Endotoxin Release and Triggers an Inflammatory Response. J. Dairy Sci. 2005, 88, 1399-1403. [CrossRef]

62. Khafipour, E.; Krause, D.; Plaizier, J. A grain-based subacute ruminal acidosis challenge causes translocation of lipopolysaccharide and triggers inflammation. J. Dairy Sci. 2009, 92, 1060-1070. [CrossRef] [PubMed]

63. Mackie, R.I.; Gilchrist, F.M.C. Changes in Lactate-Producing and Lactate-Utilizing Bacteria in Relation to $\mathrm{pH}$ in the Rumen of Sheep During Stepwise Adaptation to a High-Concentrate Diet. Appl. Environ. Microbiol. 1979, 38, 422-430. [CrossRef]

64. Tajima, K.; Aminov, R.I.; Nagamine, T.; Matsui, H.; Nakamura, M.; Benno, Y. Diet-Dependent Shifts in the Bacterial Population of the Rumen Revealed with Real-Time PCR. Appl. Environ. Microbiol. 2001, 67, 2766-2774. [CrossRef]

65. Bevans, D.W.; Beauchemin, K.A.; Schwartzkopf-Genswein, K.S.; McKinnon, J.J.; McAllister, T.A. Effect of rapid or gradual grain adaptation on subacute acidosis and feed intake by feedlot cattle1,2. J. Anim. Sci. 2005, 83, 1116-1132. [CrossRef] [PubMed]

66. Sato, S. Pathophysiological evaluation of subacute ruminal acidosis (SARA) by continuous ruminal pH monitoring. Anim. Sci. J. 2015, 87, 168-177. [CrossRef] [PubMed]

67. Burrin, D.G.; Britton, R.A. Response to Monensin in Cattle during Subacute Acidosis. J. Anim. Sci. 1986, 63, 888-893. [CrossRef] [PubMed]

68. Wang, L.; Zhang, G.; Li, Y.; Zhang, Y. Effects of High Forage/Concentrate Diet on Volatile Fatty Acid Production and the Microorganisms Involved in VFA Production in Cow Rumen. Animimals 2020, 10, 223. [CrossRef]

69. Ribeiro, R.C.O.; Villela, S.D.J.; Filho, S.V.; Santos, S.A.; Ribeiro, K.G.; Detmann, E.; Zanetti, D.; Martins, P.G.M.A. Effects of roughage sources produced in a tropical environment on forage intake, and ruminal and microbial parameters1. J. Anim. Sci. 2015, 93, 2363-2374. [CrossRef]

70. Agle, M.; Hristov, A.; Zaman, S.; Schneider, C.; Ndegwa, P.; Vaddella, V. Effect of dietary concentrate on rumen fermentation, digestibility, and nitrogen losses in dairy cows. J. Dairy Sci. 2010, 93, 4211-4222. [CrossRef] [PubMed]

71. Danfær, A. Nutrient metabolism and utilization in the liver. Livest. Prod. Sci. 1994, 39, 115-127. [CrossRef]

72. Kristensen, N.B. Rumen microbial sequestration of [2-(13)C]acetate in cattle. J. Anim. Sci. 2001, 79, 2491-2498. [CrossRef]

73. Hackmann, T.J.; Firkins, J.L. Maximizing efficiency of rumen microbial protein production. Front. Microbiol. 2015, 6, 465. [CrossRef]

74. Lana, R.P.; Russell, J.B.; Van Amburgh, M.E. The role of $\mathrm{pH}$ in regulating ruminal methane and ammonia production. J. Anim. Sci. 1998, 76, 2190-2196. [CrossRef]

75. Satter, L.D.; Slyter, L.L. Effect of ammonia concentration on rumen microbial protein production In Vitro. Br. J. Nutr. 1974, 32, 199-208. [CrossRef] [PubMed]

76. Bi, Y.; Zeng, S.; Zhang, R.; Diao, Q.; Tu, Y. Effects of dietary energy levels on rumen bacterial community composition in Holstein heifers under the same forage to concentrate ratio condition. BMC Microbiol. 2018, 18, 1-11. [CrossRef] [PubMed] 
77. Petri, R.M.; Schwaiger, T.; Penner, G.B.; Beauchemin, K.A.; Forster, R.J.; McKinnon, J.J.; McAllister, T.A. Characterization of the core rumen microbiome in cattle during transition from forage to concentrate as well as during and after an acidotic challenge. PLoS ONE 2013, 8, e83424. [CrossRef] [PubMed]

78. Mao, S.Y.; Zhang, R.Y.; Wang, D.S.; Zhu, W.Y. Impact of subacute ruminal acidosis (SARA) adaptation on rumen microbiota in dairy cattle using pyrosequencing. Anaerobe 2013, 24, 12-19. [CrossRef]

79. Fernando, S.C.; Purvis, H.T.; Najar, F.Z.; Sukharnikov, L.O.; Krehbiel, C.R.; Nagaraja, T.G.; Roe, B.A.; DeSilva, U. Rumen microbial population dynamics during adaptation to a high-grain diet. Appl. Environ. Microbiol. 2010, 76, 7482-7490. [CrossRef] [PubMed]

80. Plaizier, J.C.; Li, S.; Danscher, A.M.; Derakshani, H.; Andersen, P.H.; Khafipour, E. Changes in microbiota in rumen digesta and feces due to a grain-based subacute ruminal acidosis (SARA) challenge. Microb. Ecol. 2017, 74, 485-495. [CrossRef]

81. Kong, Y.; Teather, R.; Forster, R. Composition, spatial distribution, and diversity of the bacterial communities in the rumen of cows fed different forages. FEMS Microbiol. Ecol. 2010, 74, 612-622. [CrossRef] [PubMed]

82. Huws, S.A.; Kim, E.J.; Cameron, S.J.S.; Girdwood, S.E.; Davies, L.; Tweed, J.; Vallin, H.; Scollan, N.D. Characterization of the rumen lipidome and microbiome of steers fed a diet supplemented with flax and echium oil. Microb. Biotechnol. 2014, 8, 331-341. [CrossRef]

83. Ogata, T.; Makino, H.; Ishizuka, N.; Iwamoto, E.; Masaki, T.; Ikuta, K.; Kim, Y.-H.; Sato, S. Long-term high-grain diet altered the ruminal $\mathrm{pH}$, fermentation, and composition and functions of the rumen bacterial community, leading to enhanced lactic acid production in Japanese Black beef cattle during fattening. PLoS ONE 2019, 14, e0225448. [CrossRef] [PubMed]

84. Ogata, T.; Kim, Y.-H.; Masaki, T.; Iwamoto, E.; Ohtani, Y.; Orihashi, T.; Ichijo, T.; Sato, S. Effects of an increased concentrate diet on rumen $\mathrm{pH}$ and the bacterial community in Japanese Black beef cattle at different fattening stages. J. Vet. Med Sci. 2019, 81, 968-974. [CrossRef] [PubMed]

85. Tun, H.M.; Li, S.; Yoon, I.; Meale, S.J.; Azevedo, P.A.; Khafipour, E.; Plaizier, J.C. Saccharomyces cerevisiae fermentation products (SCFP) stabilize the ruminal microbiota of lactating dairy cows during periods of a depressed rumen pH. BMC Vet. Res. 2020, 16, 1-17. [CrossRef] [PubMed]

86. El Kaoutari, A.; Armougom, F.; Gordon, J.I.; Raoult, D.; Henrissat, B. The abundance and variety of carbohydrate-active enzymes in the human gut microbiota. Nat. Rev. Genet. 2013, 11, 497-504. [CrossRef]

87. Golder, H.; Denman, S.; McSweeney, C.; Celi, P.; Lean, I. Ruminal bacterial community shifts in grain, sugar, and histidinechallenged dairy heifers. J. Dairy Sci. 2014, 97, 5131-5150. [CrossRef] [PubMed]

88. Griswold, K.E.; White, B.A.; Mackie, R.I. Diversity of Extracellular Proteolytic Activities among Prevotella Species from the Rumen. Curr. Microbiol. 1999, 39, 187-194. [CrossRef]

89. Ze, X.; Ben David, Y.; Laverde-Gomez, J.A.; Dassa, B.; Sheridan, P.O.; Duncan, S.H.; Louis, P.; Henrissat, B.; Juge, N.; Koropatkin, N.M.; et al. Unique Organization of Extracellular Amylases into Amylosomes in the Resistant Starch-Utilizing Human Colonic Firmicutes Bacterium Ruminococcus bromii. mBio 2015, 6, e01058-15. [CrossRef]

90. Dehority, B.A. Characterization of Several Bovine Rumen Bacteria Isolated with a Xylan Medium1. J. Bacteriol. 1966, 91, 1724-1729. [CrossRef] [PubMed]

91. Hungate, R.E. The Rumen and Its Microbes, 1st ed.; Department of Bacteriology and Agricultural Experiment Station, University of California: Davis, CA, USA; Academic Press: New York, NY, USA; London, UK, 1966; ISBN 97814832636.

92. Dehority, B.A. Pectin-fermenting Bacteria Isolated from the Bovine Rumen1. J. Bacteriol. 1969, 99, 189-196. [CrossRef] [PubMed]

93. Downes, J.; Sutcliffe, I.; Tanner, A.C.R.; Wade, W.G. Prevotella marshii sp. nov. and Prevotella baroniae sp. nov., isolated from the human oral cavity. Int. J. Syst. Evol. Microbiol. 2005, 55, 1551-1555. [CrossRef]

94. Li, Z.P.; Liu, H.L.; Li, G.Y.; Bao, K.; Wang, K.Y.; Xu, C.; Yang, Y.F.; Yang, F.H.; Wright, A.-D.G. Molecular diversity of rumen bacterial communities from tannin-rich and fiber-rich forage fed domestic Sika deer (Cervus nippon) in China. BMC Microbiol. 2013, 13, 1-12. [CrossRef] [PubMed]

95. Cotta, M.A. Interaction of ruminal bacteria in the production and utilization of maltooligosaccharides from starch. Appl. Environ. Microbiol. 1992, 58, 48-54. [CrossRef]

96. Gardner, R.G.; Wells, J.E.; Russell, J.B.; Wilson, D.B. The cellular location of Prevotella ruminicola beta-1,4-D-endoglucanase and its occurrence in other strains of ruminal bacteria. Appl. Environ. Microbiol. 1995, 61, 3288-3292. [CrossRef] [PubMed]

97. Matsui, H.; Ogata, K.; Tajima, K.; Nakamura, M.; Nagamine, T.; Aminov, R.I.; Benno, Y. Phenotypic Characterization of Polysaccharidases Produced by Four Prevotella Type Strains. Curr. Microbiol. 2000, 41, 45-49. [CrossRef]

98. Krause, D.O.; Denman, S.E.; Mackie, R.I.; Morrison, M.; Rae, A.L.; Attwood, G.T.; McSweeney, C.S. Opportunities to improve fiber degradation in the rumen: Microbiology, ecology, and genomics. FEMS Microbiol. Rev. 2003, 27, 663-693. [CrossRef]

99. Whitehead, T.R. Analyses of the gene and amino acid sequence of the Prevotella (bacteroides) ruminicola 23 xylanase reveals unexpected homology with endoglucanases from other genera of bacteria. Curr. Microbiol. 1993, 27, 27-33. [CrossRef]

100. Ntougias, S.; Lapidus, A.; Han, J.; Mavromatis, K.; Pati, A.; Chen, A.; Klenk, H.-P.; Woyke, T.; Fasseas, C.; Kyrpides, N.C.; et al High quality draft genome sequence of Olivibacter sitiensis type strain (AW-6T), a diphenol degrader with genes involved in the catechol pathway. Stand. Genom. Sci. 2014, 9, 783-793. [CrossRef]

101. Bang, B.-H.; Rhee, M.-S.; Chang, D.-H.; Park, D.-S.; Kim, B.-C. Erysipelothrix larvae sp. nov., isolated from the larval gut of the rhinoceros beetle, Trypoxylus dichotomus (Coleoptera: Scarabaeidae). Antonie Leeuwenhoek 2015, 107, 443-451. [CrossRef]

102. Khan, S.T.; Nakagawa, Y.; Harayama, S. Galbibacter mesophilus gen. nov., sp. nov., a novel member of the family Flavobacteriaceae. Int. J. Syst. Evol. Microbiol. 2007, 57, 969-973. [CrossRef] [PubMed] 
103. Klieve, A.V.; O'Leary, M.N.; McMillen, L.; Ouwerkerk, D. Ruminococcus bromii, identification and isolation as a dominant community member in the rumen of cattle fed a barley diet. J. Appl. Microbiol. 2007, 103, 2065-2073. [CrossRef] [PubMed]

104. Kim, Y.-H.; Nagata, R.; Ohkubo, A.; Ohtani, N.; Kushibiki, S.; Ichijo, T.; Sato, S. Changes in ruminal and reticular pH and bacterial communities in Holstein cattle fed a high-grain diet. BMC Vet. Res. 2018, 14, 310. [CrossRef] [PubMed]

105. Van Gylswyk, N.O. Succiniclasticum ruminis gen. nov., sp. nov., a Ruminal Bacterium Converting Succinate to Propionate as the Sole Energy-Yielding Mechanism. Int. J. Syst. Bacteriol. 1995, 45, 297-300. [CrossRef] [PubMed]

106. Sheik, C.S.; Sieber, J.R.; Badalamenti, J.P.; Carden, K.; Olson, A. Complete Genome Sequence of Desulfovibrio desulfuricans Strain G11, a Model Sulfate-Reducing, Hydrogenotrophic, and Syntrophic Partner Organism. Genome Announc. 2017, 5, e01207-17. [CrossRef] [PubMed]

107. Aschenbach, J.R.; Gäbel, G. Effect and absorption of histamine in sheep rumen: Significance of acidotic epithelial damage. J. Anim. Sci. 2000, 78, 464-470. [CrossRef] [PubMed]

108. Bergman, E.N. Energy contributions of volatile fatty acids from the gastrointestinal tract in various species. Physiol. Rev. 1990, 70, 567-590. [CrossRef]

109. Aschenbach, J.R.; Borau, T.; Gäbel, G. Glucose Uptake via SGLT-1 Is Stimulated by $\beta 2$-Adrenoceptors in the Ruminal Epithelium of Sheep. J. Nutr. 2002, 132, 1254-1257. [CrossRef]

110. Krause, K.M.; Oetzel, G.R. Understanding and preventing subacute ruminal acidosis in dairy herds: A review. Anim. Feed. Sci. Technol. 2006, 126, 215-236. [CrossRef]

111. Žitňan, R.; Kuhla, S.; Sanftleben, P.; Bilska, A.; Schneider, F.; Zupcanova, M.; Voigt, J. Diet induced ruminal papillae development in neonatal calves not correlating with rumen butyrate. Vet. Med. 2012, 50, 472-479. [CrossRef]

112. Kitade, K.; Takahashi, K.; Yonekura, S.; Katsumata, N.; Furukawa, G.; Ohsuga, S.; Nishita, T.; Katoh, K.; Obara, Y. Effects of nutritional conditions around weaning on carbonic anhydrase activity in the parotid gland and ruminal and abomasal epithelia of Holstein calves. J. Comp. Physiol. B 2002, 172, 379-385. [CrossRef]

113. Sly, W.S.; Hu, P.Y. Human Carbonic Anhydrases and Carbonic Anhydrase Deficiencies. Annu. Rev. Biochem. 1995, 64, $375-401$. [CrossRef] [PubMed]

114. Zhong, K.; Zhang, C.-Y.; Zha, G.-M.; Wang, X.-J.; Jiao, X.-Q.; Zhu, H.-S.; Wang, Y.-Y. S100 calcium-binding protein A12 as a diagnostic index for subclinical mastitis in cows. Reprod. Domest. Anim. 2018, 53, 1442-1447. [CrossRef] [PubMed]

115. Däbritz, J.; Langhorst, J.; Lügering, A.; Heidemann, J.; Mohr, M.; Wittkowski, H.; Krummenerl, T.; Foell, D. Improving Relapse Prediction in Inflammatory Bowel Disease by Neutrophil-Derived S100A12. Inflamm. Bowel Dis. 2013, 19, 1130-1138. [CrossRef]

116. Bowman, M.A.H.; Heydemann, A.; Gawdzik, J.; Shilling, R.A.; Camoretti-Mercado, B. Transgenic expression of human S100A12 induces structural airway abnormalities and limited lung inflammation in a mouse model of allergic inflammation. Clin. Exp. Allergy 2011, 41, 878-889. [CrossRef]

117. Abdela, N. Sub-acute Ruminal Acidosis (SARA) and its Consequence in Dairy Cattle: A Review of Past and Recent Research at Global Prospective. Achieve Life Sci. 2016, 10, 187-196. [CrossRef]

118. Pan, X.; Hobbs, R.P.; Coulombe, P.A. The expanding significance of keratin intermediate filaments in normal and diseased epithelia. Curr. Opin. Cell Biol. 2013, 25, 47-56. [CrossRef]

119. Bond, J.J.; Donaldson, A.J.; Coumans, J.V.F.; Austin, K.; Ebert, D.; Wheeler, D.; Oddy, V.H. Protein profiles of enzymatically isolated rumen epithelium in sheep fed a fibrous diet. J. Anim. Sci. Biotechnol. 2019, 10, 1-14. [CrossRef] [PubMed]

120. Xiang, R.; Oddy, V.H.; Archibald, A.L.; Vercoe, P.E.; Dalrymple, B.P. Epithelial, metabolic and innate immunity transcriptomic signatures differentiating the rumen from other sheep and mammalian gastrointestinal tract tissues. PeerJ 2016, 4, e1762. [CrossRef] [PubMed]

121. Scocco, P.; Mercati, F.; Brusaferro, A.; Ceccarelli, P.; Belardinelli, C.; Malfatti, A. Keratinisation degree of rumen epithelium and body condition score in sheep grazing on Brachypodium rupestre. Vet. Ital. 2013, 49, 211-217.

122. Muramatsu, T. Basigin (CD147), a multifunctional transmembrane glycoprotein with various binding partners. J. Biochem. 2016, 159, 481-490. [CrossRef] [PubMed]

123. Stumpff, F.; Martens, H.; Bilk, S.; Aschenbach, J.R.; Gäbel, G. Cultured ruminal epithelial cells express a large-conductance channel permeable to chloride, bicarbonate, and acetate. Pflügers Arch. Eur. J. Physiol. 2008, 457, 1003-1022. [CrossRef]

124. Kuzinski, J.; Röntgen, M. The mRNA and protein expression of ruminal MCT1 is increased by feeding a mixed hay/concentrate diet compared with hay ad libitum diet (Short Communication). Arch. Anim. Breed. 2011, 54, 280-286. [CrossRef]

125. Müller, F.; Huber, K.; Pfannkuche, H.; Aschenbach, J.R.; Breves, G.; Gäbel, G. Transport of ketone bodies and lactate in the sheep ruminal epithelium by monocarboxylate transporter 1. Am. J. Physiol. Liver Physiol. 2002, 283, G1139-G1146. [CrossRef] [PubMed]

126. Gäbel, G.; Aschenbach, J.R. Ruminal SCFA absorption: Channelling acids without harm. In Ruminant Physiology: Digestion, Metabolism and Impact of Nutrition on Gene Expression, Immunology and Stress; Wageningen Academic Publishers: Wageningen, The Netherlands, 2006.

127. Kirat, D.; Masuoka, J.; Hayashi, H.; Iwano, H.; Yokota, H.; Taniyama, H.; Kato, S. Monocarboxylate transporter 1 (MCT1) plays a direct role in short-chain fatty acids absorption in caprine rumen. J. Physiol. 2006, 576, 635-647. [CrossRef] [PubMed]

128. Kirat, D.; Inoue, H.; Iwano, H.; Hirayama, K.; Yokota, H.; Taniyama, H.; Kato, S. Monocarboxylate transporter 1 gene expression in the ovine gastrointestinal tract. Vet. J. 2006, 171, 462-467. [CrossRef] [PubMed]

129. Hollmann, M.; Miller, I.; Hummel, K.; Sabitzer, S.; Metzler-Zebeli, B.U.; Razzazi-Fazeli, E.; Zebeli, Q. Downregulation of Cellular Protective Factors of Rumen Epithelium in Goats Fed High Energy Diet. PLoS ONE 2013, 8, e81602. [CrossRef] 
130. Bondzio, A.; Gabler, C.; Badewien-Rentzsch, B.; Schulze, P.; Martens, H.; Einspanier, R. Identification of differentially expressed proteins in ruminal epithelium in response to a concentrate-supplemented diet. Am. J. Physiol. Liver Physiol. 2011, 301, G260-G268. [CrossRef]

131. Zhao, K.; Chen, Y.H.; Penner, G.B.; Oba, M.; Guan, L.L. Transcriptome analysis of ruminal epithelia revealed potential regulatory mechanisms involved in host adaptation to gradual high fermentable dietary transition in beef cattle. BMC Genom. 2017, 18, 976. [CrossRef] 